IOS Press

\title{
A comparison of bioactive compounds of strawberry fruit from Europe affected by genotype and latitude
}

\author{
M. Josuttis ${ }^{\mathrm{a}}$, C. Carlen ${ }^{\mathrm{b}}$, P. Crespo ${ }^{\mathrm{b}}$, R. Nestby ${ }^{\mathrm{c}}$, T.B. Toldam-Andersen ${ }^{\mathrm{d}}$, H. Dietrich ${ }^{\mathrm{e}}$ and E. Krüger ${ }^{\mathrm{f}, *}$ \\ ${ }^{a}$ RheinMain University of Applied Sciences, Geisenheim, Germany \\ ${ }^{\mathrm{b}}$ Agroscope Changins-Wädenswil, Research Station ACW, Changins-Wädenswil, Switzerland \\ ${ }^{\mathrm{c}}$ Bioforsk, Grasland and Landscape Division Kvithamar, Stjørdal, Norway \\ ${ }^{\mathrm{d}}$ Department of Agricultural Sciences, Copenhagen University, Copenhagen, Denmark \\ ${ }^{\mathrm{e}}$ Geisenheim Research Center, Department of Wine Analysis and Beverage Research, Geisenheim, Germany \\ ${ }^{\mathrm{f}}$ Geisenheim Research Center, Department of Pomology, Geisenheim, Germany
}

Received 25 August 2011; accepted 20 November 2011

\begin{abstract}
The effect of four different growing locations from Stjørdal, Norway $\left(63^{\circ} 36^{\prime} \mathrm{N}\right)$ to Conthey, Switzerland $\left(46^{\circ} 12^{\prime} \mathrm{N}\right)$ on the composition of bioactives in strawberry (Fragaria x ananassa Duch.) of three genotypes (cvs Clery, Elsanta and Korona) was evaluated. Principal component analysis (PCA) was used to characterize differences in bioactives between genotypes within a location. Despite harvest period and year-to-year effects, a clear clustering related to the effects of the cultivars was shown. Furthermore, PCA was able to separate locations within a cultivar due to differences in bioactive compounds and this effect was stronger than local variations by temporary weather changes or even year-to-year effects. As a result, the northern samples had principally lower anthocyanin amounts than the southern ones and, moreover, distribution of individual anthocyanins was different. In contrast, the content of vitamin $\mathrm{C}$ and the antioxidant capacity (TEAC, ORAC, total phenols) was generally increased with higher latitudes calculated on a fresh weight basis. Results of proanthocyanidins and individual polyphenols detected by high performance liquid chromatography indicated that the higher contents were mainly due to tannin-related components. For all these observations, cultivars responded in general similarly. A North-South division was identified but no clear trend towards latitude could be recorded, mainly since one major impact factor for the biosynthesis of phenolics and ascorbic acid is temperature, which is altering not only by latitude, but also by the shift of the harvest period and the current weather conditions prior to harvest. In conclusion, genetic effects were generally stronger than environmental effects.
\end{abstract}

Keywords: Fragaria $\mathrm{x}$ ananassa, anthocyanins, environment, antioxidant activity, polyphenols, vitamin C

\section{Introduction}

Strawberry is the most important berry crop in Europe [3]. The fruit is not only a rich source for ascorbic acid, but also for a diversity of polyphenols including anthocyanins, phenolic acids, flavonols, flavanols, ellagitannins or proanthocyanidins $[1,8]$. A number of epidemiological studies showed that these components may play a significant role due to their antioxidant capacity in the prevention of degenerative diseases such as cancer or cardiovascular burden

${ }^{*}$ Corresponding author: Erika Krüger, Geisenheim Research Center, Department of Pomology, Von-Lade-Str. 1, 65366 Geisenheim, Germany. Tel.: +49 672250563; Fax: +49 6722502560; E-mail: Krueger@fa-gm.de. 
$[16,41,46]$. Internal and external factors as cultivar and environment contribute to the content and composition of these secondary plant metabolites in the fruit $[4,5,8,11,34,40,45]$. Until now, little is known about variability in health-promoting substances in berry fruit affected by growing locations at different latitudes [20]. Strawberries are produced in almost all parts of Europe differing in harvest season, locally adapted cultivars and cultivation systems [14]. The main environmental effects changing with latitude are the temperature and the day length including light quality as well as quantity of the solar radiation. Earlier studies showed that high temperature during fruit development increases the content of several bioactives in strawberry and raspberry [21, 37, 49], whereas results connected to the impact of light are scarce and limited to UVB radiation [22, 32] and shading [4]. These results indicated that the content of bioactives may decrease in strawberries from northern parts of Europe due to low temperatures. The aim of our study was to evaluate the differences of four growing locations with a distance of more than $2000 \mathrm{~km}$ located from Norway to Switzerland with respect to the impact of genotype, harvest period, and year.

\section{Materials and methods}

\subsection{Field experiments and climatic data}

The trial was conducted in 2008 and 2009 at the locations Stjørdal, Norway $=\mathrm{N}\left(63^{\circ} 36^{\prime} \mathrm{N}\right)$, Geisenheim, Germany $=\mathrm{D}\left(49^{\circ} 59^{\prime} \mathrm{N}\right)$, and Conthey, Switzerland $=\mathrm{CH}\left(46^{\circ} 12^{\prime} \mathrm{N}\right)$. In 2009 , strawberries were also collected in Copenhagen, Denmark $=\operatorname{Dk}\left(55^{\circ} 40^{\prime} \mathrm{N}\right)$. At each side, strawberries were purchased from local nursery companies and cultivated typically for the mentioned growing regions as described by Krüger et al. [24]. The experiments were carried out under open-field conditions using three June-bearing strawberry cultivars (Fragaria x ananassa Duch.); cv. Elsanta was grown as standard at all locations. Additionally, cv. Korona as cultivar adapted to the Northern European climate conditions was planted at the northern regions (N, DK, D) and cv. Clery was cultivated at the southern ones $(\mathrm{D}, \mathrm{CH})$ as cultivar with major importance in Central and Southern Europe. The experimental set up at the different locations involved three replications with 15 to 40 plants per plot. On all areas air temperature and photosynthetically active radiation (PAR) were measured and calculated during the fruit development period starting 28 days before the first harvest sampling (Table 1).

\subsection{Sampling and sample preparation}

Three independent biological replications were collected at the second and third week of the harvest period at each location per cultivar. All samples contained not less than $500 \mathrm{~g}$ of non-damaged and healthy fruit including green

Table 1

Growing conditions of the different locations 28 days prior to first picking ${ }^{\mathrm{a}}$

\begin{tabular}{|c|c|c|c|c|c|c|c|}
\hline \multirow{2}{*}{$\begin{array}{l}\text { Origin } \\
\text { Year }\end{array}$} & \multicolumn{2}{|c|}{ Norway } & \multirow{2}{*}{$\begin{array}{c}\text { Denmark } \\
2009\end{array}$} & \multicolumn{2}{|c|}{ Germany } & \multicolumn{2}{|c|}{ Switzerland } \\
\hline & 2008 & 2009 & & 2008 & 2009 & 2008 & 2009 \\
\hline Latitude & \multicolumn{2}{|c|}{$63^{\circ} 36^{\prime} \mathrm{N}$} & $55^{\circ} 40^{\prime} \mathrm{N}$ & \multicolumn{2}{|c|}{$49^{\circ} 59^{\prime} \mathrm{N}$} & \multicolumn{2}{|c|}{$46^{\circ} 12^{\prime} \mathrm{N}$} \\
\hline Soil type & \multicolumn{2}{|c|}{ Silty loam } & Sandy loam & \multicolumn{2}{|c|}{ Sandy loam } & \multicolumn{2}{|c|}{ Sandy loam } \\
\hline Day length at harvest begin [h] & \multicolumn{2}{|c|}{20.3} & 17.5 & \multicolumn{2}{|c|}{15.8} & \multicolumn{2}{|c|}{15.1} \\
\hline Sum PAR per day $\left[\mathrm{mol} \mathrm{m}^{-2} \mathrm{~d}^{-1}\right]$ & $46.0 \mathrm{a}$ & $42.2 \mathrm{a}$ & $24.7 b$ & $28.2 \mathrm{~b}$ & $31.4 \mathrm{~b}$ & $45.9 \mathrm{a}$ & $41.7 \mathrm{a}$ \\
\hline Begin of flowering & 26.05 & 04.06 & 11.05 & 26.04 & 16.04 & 25.04 & 17.04 \\
\hline \multirow[t]{2}{*}{ Harvest begin } & 03.07 & 03.07 & 16.06 & 27.05 & 18.05 & 16.05 & 18.05 \\
\hline & & & Daily temperatu & & & & \\
\hline Mean $\left[{ }^{\circ} \mathrm{C}\right]$ & $13.8 \mathrm{~d}$ & $15.9 \mathrm{bcd}$ & $14.2 \mathrm{~cd}$ & $19.2 \mathrm{a}$ & $16.3 \mathrm{bc}$ & $17.1 \mathrm{ab}$ & $17.4 \mathrm{ab}$ \\
\hline $\operatorname{Min}\left[{ }^{\circ} \mathrm{C}\right]$ & $8.9 \mathrm{~cd}$ & $10.6 \mathrm{bc}$ & $9.8 \mathrm{bcd}$ & $13.8 \mathrm{a}$ & $8.3 \mathrm{~d}$ & $11.1 \mathrm{~b}$ & $11.0 \mathrm{~b}$ \\
\hline $\operatorname{Max}\left[{ }^{\circ} \mathrm{C}\right]$ & $18.1 \mathrm{c}$ & $20.9 \mathrm{bc}$ & $18.4 \mathrm{c}$ & $25.2 \mathrm{a}$ & $24.0 \mathrm{ab}$ & $23.0 \mathrm{ab}$ & $24.1 \mathrm{ab}$ \\
\hline
\end{tabular}

${ }^{a}$ Means within the same row followed by different letters were significantly different at $p<0.05$ (Tukey's test). 
calyx. Each fruit was sliced and shock frozen in liquid nitrogen as previously described by Josuttis et al. [22] and milled to powder later. The frozen powder from all locations was sent on dry ice to the Geisenheim Research Center, where the following analysis were performed as reported [22].

\subsection{Quality attributes: Soluble solids content (SSC), titratable acidity (TA), and dry matter (DM)}

After thawing the frozen strawberry powder, the resulting puree was directly measured with a digital refractometer (A. Krüss Optotronic GmbH, Hamburg, Germany) for soluble solids content (SSC). The dry matter (DM) content was determined by mixing the powder $(5 \mathrm{~g})$ with sea sand and drying for $4 \mathrm{~h}$ hours at $103^{\circ} \mathrm{C}$. For the determination of titratable acidity (TA) five grams of powder was homogenized in $50 \mathrm{~mL}$ water, equilibrated for one hour and titrated with $0.33 \mathrm{~mol} \mathrm{~L}^{-1}$ sodium hydroxide solution to a $\mathrm{pH}$ value of 8.1 . All results were expressed as $\%$ of fresh weight.

\subsection{Ascorbic acid (AA)}

Due to high ascorbic acid (AA) contents in strawberry fruit it was possible to determine the concentration by iodometric titration adapted to Ballentine [6] and Matissek and Steiner [28]. Therefore, the frozen strawberry powder $(5 \mathrm{~g})$ was extracted twice with $10 \mathrm{~mL}$ of $2 \%$ oxalic acid $(\mathrm{w} / \mathrm{v})$, centrifuged, the collected supernatants were acidified with $10 \%$ sulfuric acid (v/v), and immediately titrated potentiometrically with $1 / 128 \mathrm{~mol} \mathrm{~L}^{-1}$ iodide-iodate-solution. Results were calculated as $\mu \mathrm{g}$ AA per $\mathrm{g}$ fresh weight.

\subsection{Antioxidant capacity: Total phenols (TP), trolox equivalent antioxidant capacity (TEAC), and oxygen radical absorbance capacity (ORAC)}

All parameters were analysed from the methanolic extracts as previously described [22]. Briefly, frozen strawberry powder $(5 \mathrm{~g})$ was extracted twice ultrasound-assisted for $30 \mathrm{~min}$ with $80 \%$ methanol. Total phenols (TP) were analysed by Folin-Ciocalteu method as gallic acid equivalents (GAE) according to Singleton et al. [42]. Therefore, the diluted extract was mixed with Folin-Ciocalteu reagent and after five minutes saturated sodium carbonate solution was added. The absorbance was measured after $60 \mathrm{~min}$ at $760 \mathrm{~nm}$. Results were expressed in $\mu \mathrm{g}$ GAE per $\mathrm{g}$ fresh weight. The TEAC value was determined according to Re et al. [36]; thus an ABTS [2,2'-azino-bis-(3-ethylbenzthiazoline-6sulphonic acid)] radical cation solution was generated overnight with potassium persulfate and a final absorbance of $0.800 \pm 0.050$. This solution was mixed in a ratio of $1: 5$ with the diluted extracts. The absorbance was measured after $6 \mathrm{~min}$ at $734 \mathrm{~nm}$. The ORAC assay was carried out using fluorescein and a black 96-well plate according to Ou et al. [33] and Huang et al. [19]. The analysis was carried out on a black 96-well plate with a microplate reader (Infinite M200, Tecan). Each well was filled with a $20 \mu \mathrm{L}$ diluted sample, blank or Trolox standard and $120 \mu \mathrm{L}$ of fluorescein. After $5 \mathrm{~min}$ incubation $60 \mu \mathrm{L}$ of AAPH-solution was added. The fluorescence was recorded every minute for $90 \mathrm{~min}$ at $37^{\circ} \mathrm{C}$ with an excitation wavelength of $485 \mathrm{~nm}$ and an emission wavelength of $520 \mathrm{~nm}$. The ORAC values refer to the net area under the quenching curve and were calculated after linear regression of the AUC. The ORAC as well as the TEAC results were expressed as trolox equivalents (TE) in $\mu \mathrm{g}$ per $\mathrm{g}$ fresh weight.

\subsection{Total monomeric anthocyanins (TMA)}

Total monomeric anthocyanins were analysed by the $\mathrm{pH}$ differential method. The above mentioned methanolic extracts were diluted with two buffers in a ratio of $1: 10(\mathrm{v} / \mathrm{v})$ at $\mathrm{pH} 1$ with $0.025 \mathrm{~mol} \mathrm{~L}^{-1}$ potassium chloride buffer and at $\mathrm{pH} 4.5$ with $0.4 \mathrm{~mol} \mathrm{~L}^{-1}$ sodium acetate buffer. The diluted sample was measured at a wavelength of $500 \mathrm{~nm}$ and $700 \mathrm{~nm}$. The results were calculated with a molar absorption coefficient of $15.600 \mathrm{~L} \mathrm{~mol}^{-1} \mathrm{~cm}^{-1}$ as pelargonidin 3 -glucoside in $\mu \mathrm{g}$ per $\mathrm{g}$ fresh weight [12].

\subsection{Proanthocyanidin (PAC) content}

The content of proanthocyanidins (PAC) was determined colorimetrically using $0.1 \% \quad(\mathrm{w} / \mathrm{v})$ 4-dimethylaminocinnamaldehyde (DMAC; Agros Organics, Geel, Belgium) according to Prior et al. [35]. 

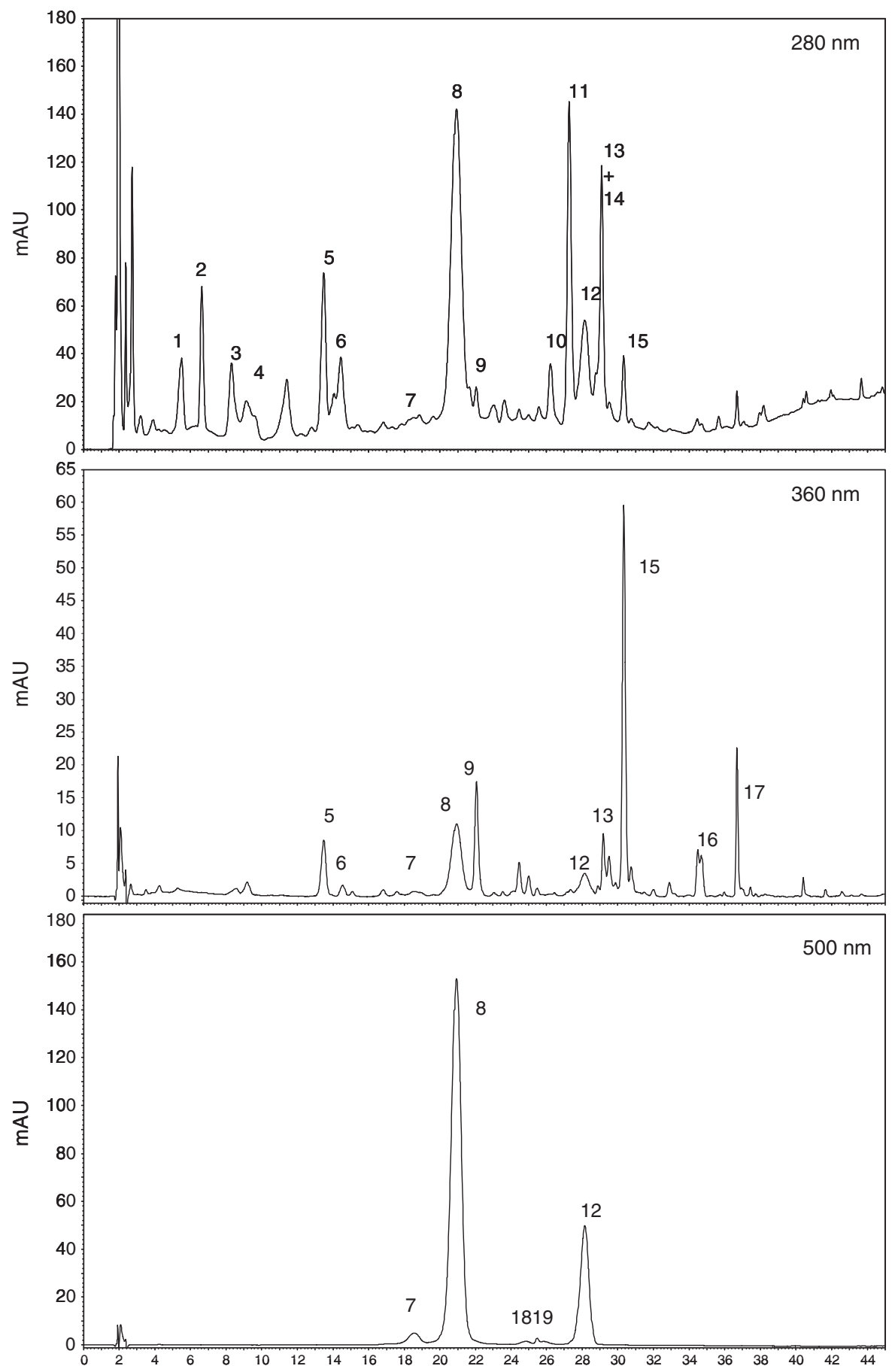

Fig. 1. HPLC chromatograms of phenolic compounds obtained at 280, 360, and $500 \mathrm{~nm}$ (cv. Elsanta). Peaks: $1=$ unknown1, $2=$ unknown2, 3 = galloyl bis HHDP-glucose, 4 = proanthocyanidins, $5=p$-coumaroyl glucose ( $p$-COUM-GLU), $6=p$-coumaroyl glucose derivative $(p$-COUMGLU derivative), 7 = cyanidin 3-glucoside (CYA 3-GLU), $8=$ pelargonidin 3-glucoside (PEL 3-GLU) $9=$ ferulic acid derivative, $10=$ ellagitannin 1 (ET_1), 11 = ellagitannin2 (ET_2), 12 = pelargonidin 3-malonylglucoside (PEL 3-GLU-MAL), 13 = ellagic acid derivative (EA-derivative), $14=$ ellagitannin3 (ET_3), 15=quercetin 3-glucuronide (QUER 3-GLC), 16=kaempferol 3-glucoside and kaempferol 3-glucuronide (KAE 3-GLU), 17 = kaempferol 3-malonylglucoside (KAE 3-GLU-MAL), 18 = cyanidin 3-malonylglucoside (CYA 3-GLU-MAL), $19=$ pelargonidin 3-derivative (PEL derivative). 
Diluted samples were mixed in a ratio of $1: 4$ with a solution of $0.1 \%$ DMAC solved in $50 \%$ of ethanol (v/v) and acidified with hydrochloric acid. The absorbance of this mixture was measured after $30 \mathrm{~min}$ at $640 \mathrm{~nm}$ and calculated as catechin (CAT) equivalents in $\mu \mathrm{g}$ per $\mathrm{g}$ fresh weight.

\subsection{High-performance liquid chromatography (HPLC) analysis of individual phenolics}

For separating and quantifying individual phenolics, HPLC analysis was performed with the prepared methanolic extracts using a ThermoFinnigan Surveyor HPLC system coupled with a photodiode array detector (PDA), pump, and autosampler controlled by Chromquest 4.1 software. The sample was injected using a Reprosil-PurC18AQ (Dr. Maisch GmbH, Ammerbuch-Entringen, Germany) column $(150 \times 2 \mathrm{~mm}, 3 \mu \mathrm{m})$. Eluent A was $2 \%$ acetic acid and Eluent B contained acetonitrile/water/acetic acid (50/49.5/0.5) according to the following gradient: 0-31.5 min, 55\% B; 31.5-37.5 min, $100 \% \mathrm{~B}$; 37.5-41.0 min, $10 \% \mathrm{~B}$ with a flow of $200 \mu \mathrm{L} \mathrm{min}^{-1}$ and an equilibration time of $10 \mathrm{~min}$. The three channels $280 \mathrm{~nm}, 360 \mathrm{~nm}$, and $500 \mathrm{~nm}$ were scanned and the main phenolic substances (Fig. 1) were calculated with available standards and expressed as $\mu \mathrm{g}$ per $\mathrm{g}$ fresh weight (Tables 2, 3).

\subsection{Determination of ellagic acid after methanolic hydrolysis}

Conjugated ellagic acid and ellagitannins were analysed after hydrolysis as ellagic acid equivalents. Frozen strawberry powder $(1.5 \mathrm{~g})$ was suspended with $5 \mathrm{~mL}$ of $50 \%$ methanol containing $1.2 \mathrm{~mol} \mathrm{~L}^{-1}$ hydrochloric acid and incubated at $80^{\circ} \mathrm{C}$ for $8 \mathrm{~h}$ according to Häkkinen et al. [13]. The hydrolyzed extract was made-up to final volume of $10 \mathrm{~mL}$ in a volumetric flask, filtrated, and analysed with the same HPLC system as described above on an ODS-A (Dr. Maisch GmbH, Ammerbuch-Entringen, Germany) column $(125 \times 2 \mathrm{~mm}, 5 \mu \mathrm{m})$. The mobile phase was $5 \%$ formic acid (A) and methanol (B) according to the following gradient: 0-25 min, 50\% B; 25-37 min, $90 \% \mathrm{~B} ; 37 \mathrm{~min}-39 \mathrm{~min}$; $10 \% \mathrm{~B} ; 39 \mathrm{~min}-46 \mathrm{~min}, 10 \% \mathrm{~B}$ with a flow of $200 \mu \mathrm{L} \mathrm{min}^{-1}$. The amount of ellagic acid was calculated at a wavelength of $255 \mathrm{~nm}$ and given in $\mu \mathrm{g}$ per $\mathrm{g}$ fresh weight.

\subsection{Statistical analysis}

The data were analysed statistically with analysis of variance using SPSS version 17 . The means of all samples at each harvest were compared with Tukey's test or Tamhane's test to calculate significant differences $(P \leq 0.05$, Tables 2-4). For the latter, homogeneity of variances is not necessary. In order to improve the clarity of the results and to understand the relationship of this data set a principal component analysis (PCA) was performed with XLSTAT 2010 including the bioactive compounds (Figs. 2, 4-7). In this way, the influence of all parameters can be illustrated simultaneously. For this reason, the score plot was used to display the distribution of samples of the data set and the loading plot to explain a possible grouping of samples and, furthermore, to show importance and interactions of the variables. To provide comparable weights for all parameters, all obtained data were autoscale-preprocessed. Therefore, each variable was mean centered and variance was scaled to unity. For PCA, ascorbic acid (AA), total monomeric anthocyanins (TMA), total phenols (TP), TEAC, ORAC, ellagic acid (EA) after hydrolysis, proanthocyanidins (PAC) and the main peaks of the HPLC analysis (peak no. 1, 2, 5-8, 11, 16, 17 in Fig. 1) were considered. To avoid an overweight of anthocyanins, only the results of the individual anthocyanins pelargonidin 3-glucoside, as the main pelargonidin related anthocyanin and cyanidin 3-glucoside, as the main cyanidin related anthocyanin, were integrated.

\section{Results and discussion}

\subsection{Effect of genotype, harvest period, and year on bioactive components}

Different genotypes are distinguished not only by plant performance, yield and fruit quality [24], they can as well be classified by their bioactives [8-10,44]. For all detected parameters a significant effect of the cultivar was detected (Tables 2-4). Principal component analysis (PCA) was used to characterize three cultivars grown in Germany sampled 

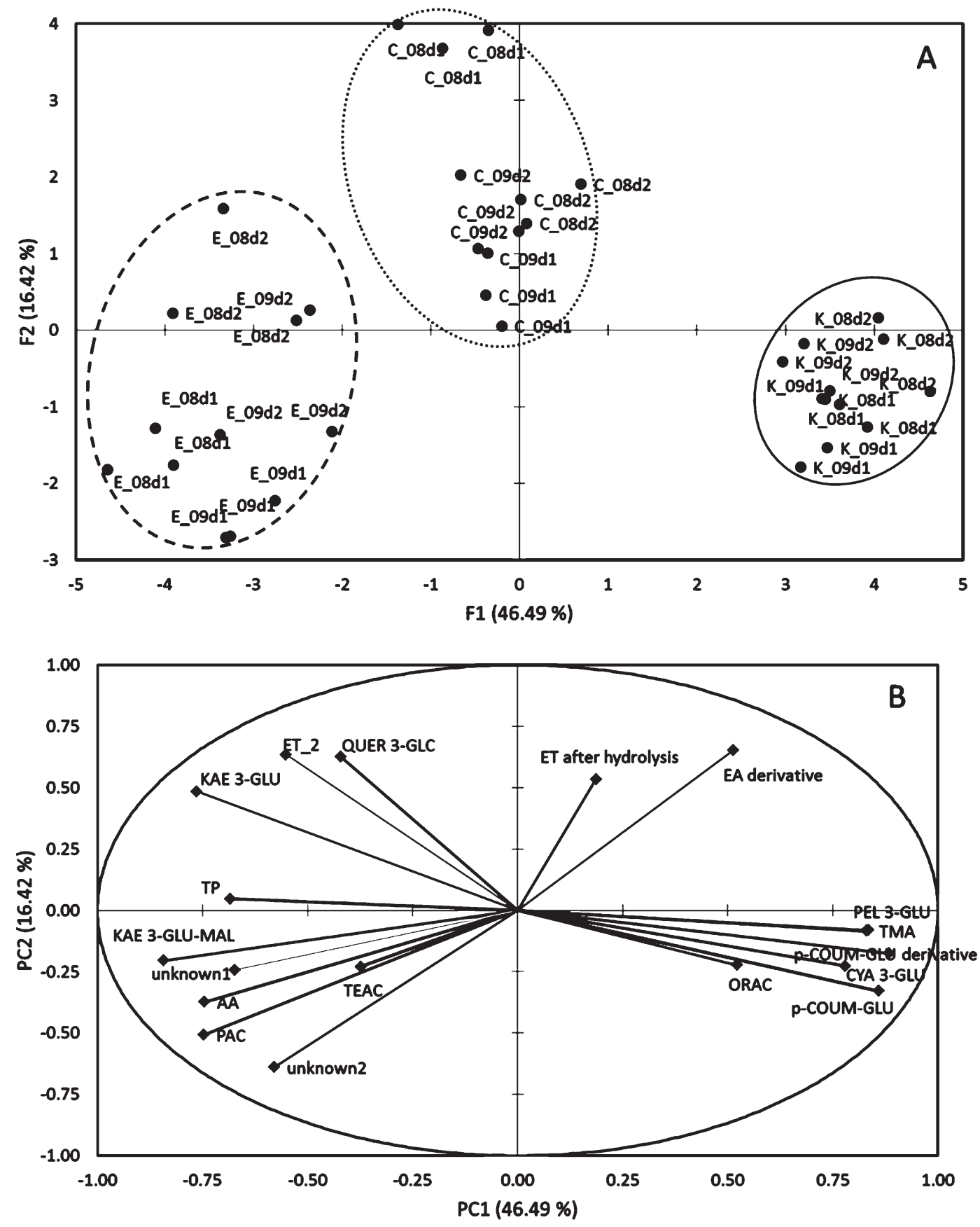

Fig. 2. Principal component analysis (PC1 and PC2) of three different cultivars grown in Germany displayed in the score plot (A) characterized by bioactive components shown in the loading plot (B). Kaempferol 3-glucoside includes kaempferol 3-glucuronide. Abbreviations used - cultivars: E, Elsanta; C, Clery; K, Korona. The number indicates the experimental year 08 for 2008 and 09 for 2009. The ending _d1 indicates the sampling during the harvest period in week 1 and _d2 the sampling in week 2 of the harvest period. All other abbreviations see legend Fig. 1. 

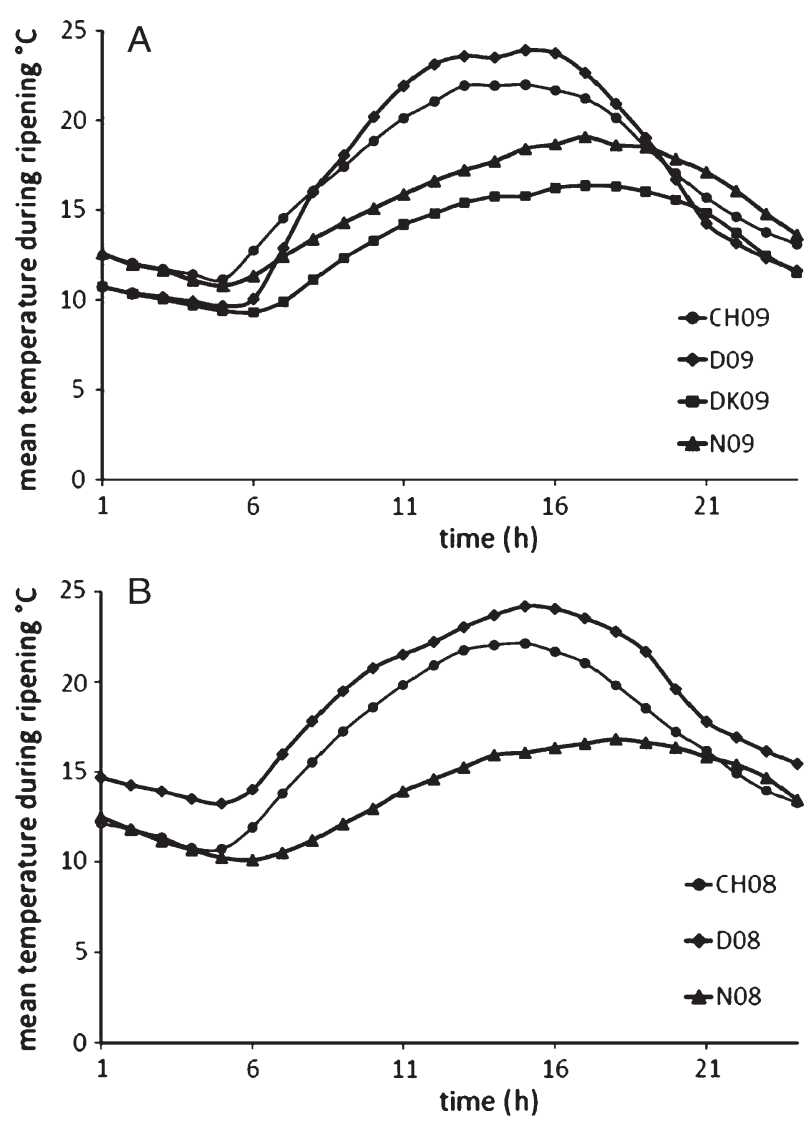

Fig. 3. Average daily temperature profile at the different locations using the hourly mean temperature during ripening (28 days before first picking) in 2008 (A) and 2009 (B). D, Germany; CH, Switzerland; Dk, Denmark; N, Norway.

at four dates in two years (Fig. 2). A clear clustering of these samples by the three genotypes was achieved (Fig. 2A). The separation was mainly due to principal component (PC) 1 with an explanation of $49.49 \%$. The main differences of the cultivars occurred among cv. Korona and cv. Elsanta. In fact, cv. Clery was located between these two cultivars, but showed more similarities to cv. Elsanta than to cv. Korona. This observation agrees with the genetic background of the cultivars since cv. Elsanta is one parent of cv. Clery (Breeder: Consorzio Italiano Vivaisti). Cutivar Korona was specified by increased ORAC levels, whereas cv. Elsanta was more characterized by a high antioxidant capacity using TP or TEAC assay. Throughout this cultivar dependent comparison, cv. Korona was described by the anthocyanin contents like pelargonidin 3-glucoside and cyanidin 3-glucoside and by the phenolic acid $p$-coumaroyl glucose, containing around 80\% (33\%) more pelargonidin 3-glucoside than cv. Elsanta (Clery). The amount of cyanidin 3glucoside was about 6-fold higher than of the other two cultivars and the level of $p$-coumaroyl glucose was twice as high (Table 3). These substances were linked to the antioxidant capacity measured by ORAC. $p$-Coumaroyl glucose and anthocyanins have in common, that they are, in contrast to other flavonoids, accumulated very late during the fruit development at the turning ripening stage from white to red [9]. However, cv. Elsanta was better described by PAC and ascorbic acid, which were associated to TEAC and TP. Furthermore, the flavonol quercetin 3-glucuronide and all analysed kaempferols were linked to the latter and played a major role in characterizing the cvs Elsanta and Clery. PC2 explained $16.42 \%$ of the data and described primarily the variation of harvest period and year. In several publications, a year-to-year effect is mentioned [45]. In the present study the day of sampling during the harvest period within one year affected the composition of bioactives to some extend similarly strong as the year (Tables $2-4$, Fig. 2A). Regarding the distribution of the samples no clear trend was notable: More exactly, a general rule of effects by sampling year or first and second sampling during the harvest period could not be established. This result was also 

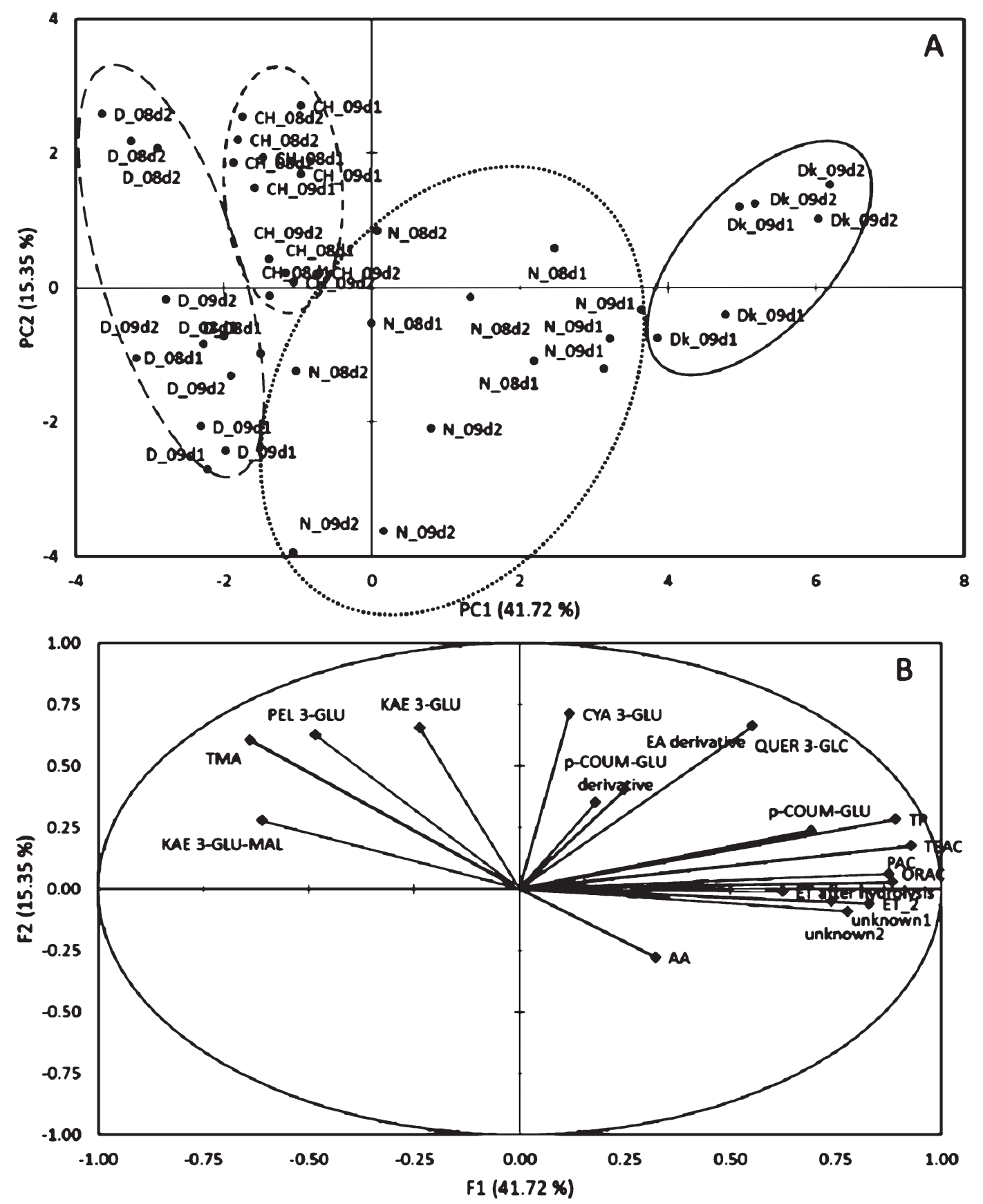

Fig. 4. Principal component analysis (PC1 and PC2) of cv. Elsanta grown at four different locations (D, Germany; CH, Switzerland; Dk, Denmark; $\mathrm{N}$, Norway) displayed in the score plot (A) characterized by bioactive components shown in the loading plot (B). Kaempferol 3-glucoside includes kaempferol 3-glucuronide. The number indicates the experimental year 08 for 2008 and 09 for 2009. The ending _d1 indicates the sampling during the harvest period in week 1 and _d2 the sampling in week 2 of the harvest period. 
confirmed by data from the other locations (Figs. 4A, 5A). In fact, from beginning to the end of the harvest different proportion of primary and secondary fruit arise [10]. Although fruit order affects the content of bioactives [4, 31], the present study showed according to the previously mentioned result that this influence is compared to other factors such as genotype and environment of minor importance. Accordingly, short-term weather changes could be sufficient affecting the biosynthesis of bioactives.

\subsection{Environmental impact on bioactives of strawberry fruit}

\subsubsection{Growing conditions of strawberries at different latitudes}

The growing conditions of the different locations and the effects on harvest period, growth, yield, and fruit quality of strawberry such as firmness, soluble solids content, total acidity were discussed in detail throughout the connected publication by Krüger et al. [24]. Therefore, the main characteristics of the growing locations will be mentioned herein only briefly. The four sites were located in a distance of 17 degrees of latitude. The beginning of flowering and the harvest period started later at the northern locations, which resulted in an extended day-length during the harvest periods (Table 1). However, no direct relation was observed considering the day-length and PAR values of the locations (Table 1). The average annual temperature of the different locations was lower with higher latitude causing a delay of harvest season [24]. As a result, the mean temperature and the current weather during the fruit maturation were not directly dependent by the degree of latitude (Table 1, Fig. 3). The northern and southern locations differed in the daily temperature profiles during the ripening process (Fig. 3). Whereas the southern locations have a steep curve progression with a daily maximum at the early afternoon, moreover, the daily maximum temperature was reached later. The daily temperature profile at the northern locations was shallower because of minor temperature differences during the day.

\subsubsection{Latitude contribute to the composition of bioactives}

The growing location affected the content of several bioactives in strawberries. Plants of cv. Elsanta were grown at all locations and a comparison of strawberry fruit samples from four different origins was possible. Likewise, PCA was used to characterize the influence of latitude and the result were displayed by PC1 and PC2 explaining 57.07\% of the data (Fig. 4). PC1 (41.72\%) was mainly responsible for the separation by origin, whereas PC2 explained the distribution of year and harvest period by only $15.35 \%$. This indicated that latitude had a stronger impact on bioactives than local and temporary weather changes or even year-to-year differences. The major differences were observed between samples from Germany and Denmark. During ripening, the daily sum of PAR was not different for these two locations, but the temperature in Denmark was lower than in Germany (Fig. 3, Table 1). The samples from Norway were located between these two clusters and showed the highest variation among the observations affected by harvest period and experimental year (Fig. 4). Furthermore, minor homogeneity of the three replications within this cultivar existed for the Norwegian samples compared to the other origins, which was shown by the distance of the observations (Fig. 4). In contrast, the temperature at the two locations was similar. It could be concluded by the assessment of these environmental factors that the effect of PAR was less important. The Swiss and German samples were located very close, although the average sum of daily PAR during ripening was higher in Switzerland than in Germany (Table 1). On the one hand the Swiss and German samples were very similar despite different PAR values and on the other hand German and Danish samples showed overall the greatest differences although PAR values were very similar.

The content of total anthocyanins was one factor to segregate the samples of different locations. The southern fruit samples contained more total anthocyanins than the northern ones (Table 2, Fig. 4). As expected, the total anthocyanin content was strongly related to the major anthocyanin pelargonidin 3-glucoside, however, no or only a weak interaction with cyanidin 3-glucoside was observed for samples of cv. Elsanta (Fig. 4). In addition, the content of total anthocyanins was connected to the kaempferol content. The northern samples were directed to a high antioxidant capacity measured using all three assays TEAC, ORAC, and TP. As shown in Fig. 4, this effect was related to the contents of PAC, ellagitannis, $p$-coumaroyl glucose, quercetin 3-glucuronide, and two unknown components (peak 1 and 2 in Fig. 1). For the Danish samples only one-year results were available, which showed for cv. Elsanta the highest contents in antioxidant capacity and tannin-related components like PAC and ellagitannins determined after hydrolysis (Table 3). The samples from cooler regions contained generally higher ascorbic acid levels (Fig. 4, 

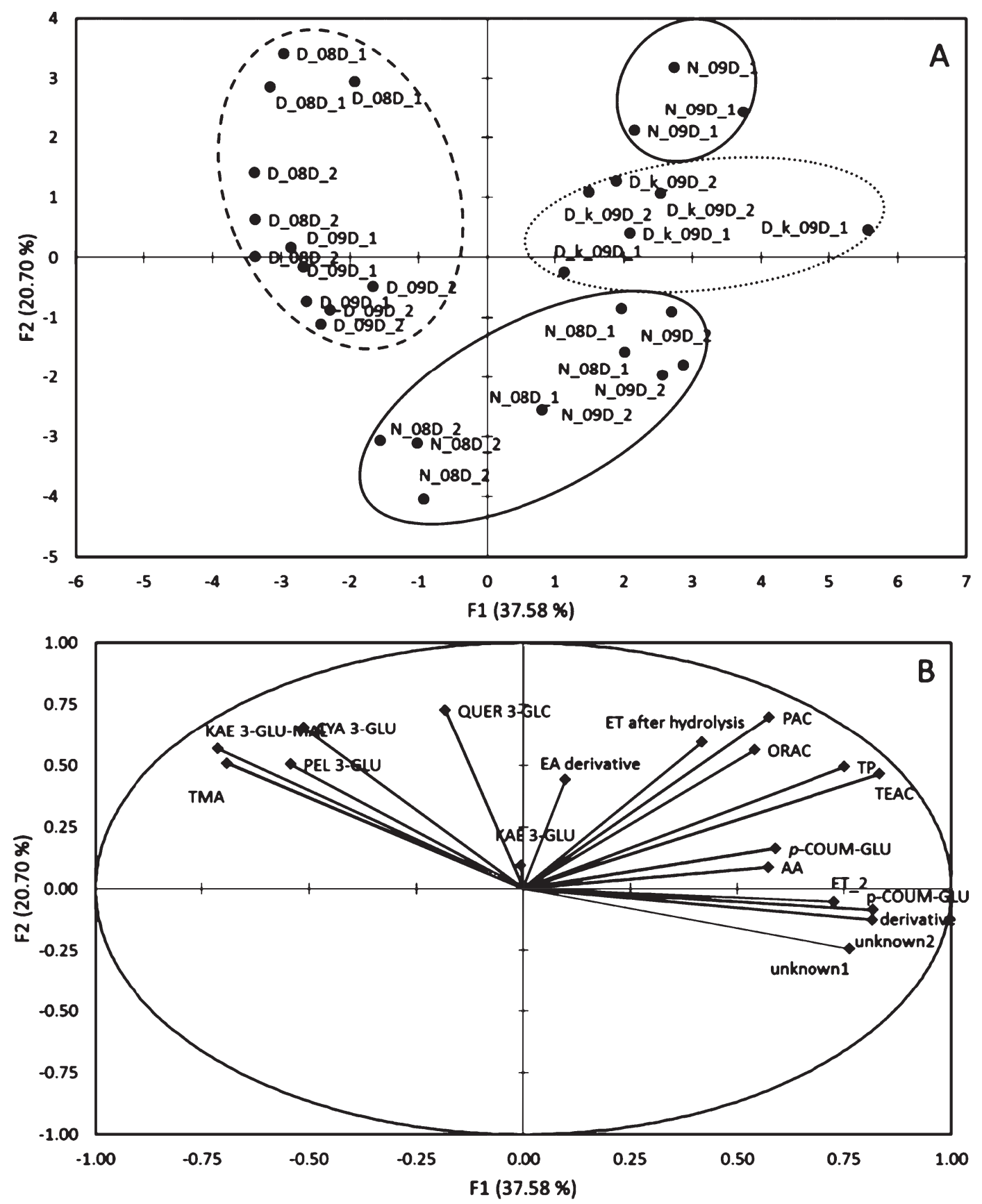

Fig. 5. Principal component analysis (PC1 and PC2) of cv. Korona grown at three different locations (D, Germany; Dk, Denmark; N, Norway) displayed in the score plot (A) characterized by bioactive components shown in the loading plot (B). Kaempferol 3-glucoside includes kaempferol 3-glucuronide. The number indicates the experimental year 08 for 2008 and 09 for 2009 . The ending _d 1 indicates the sampling during the harvest period in week 1 and _d 2 the sampling in week 2 of the harvest period. 
Table 4). Regarding only one of the mentioned parameter, a location effect was notable, but this effect was masked due to high variation of harvest period and year (Tables 2-4).

Principal component analysis (PCA) of cv. Korona were displayed by PC1 and PC2 explaining 58.28\% of the data (Fig. 5). The samples were clustered by origin, but additionally, strongly by the year. Especially the Norwegian samples showed a high variation within the harvest period and years and were thus not completely distinguishable from the Danish samples. Nevertheless, a north (Dk, N) to south partition (D) was observed (Fig. 5) by PC1 explaining 37.58\% of the data. The data were splitted because of their contents of anthocyanins and kaempferol 3-malonylglucoside. In contrast to the previous cv. Elsanta, the anthocyanin cyanidin 3-glucoside was definitely related to the content of total anthocyanins and pelargonidin 3-glucoside for cv. Korona. However, in agreement with the results of cv. Elsanta, cyanidin 3-glucoside and quercetin 3-glucoside were connected (Fig. 5). The impact of kaempferol 3-glucoside was very low, possibly due to low contents of cv. Korona compared to the other cultivars (Table 3). As well as for cv. Elsanta, it was confirmed that fruit of cv. Korona from the northern regions tended to elevated ascorbic acid and $p$-coumaroyl glucose levels. Antioxidant capacity determined by TP, TEAC, and ORAC was linked to the contents of PAC, ellagitannins, and the two unknown components (peak 1 and 2 in Fig. 1).

The third analysed cv. Clery was not discriminable by the origin. Precisely, the variability of the yearly means was stronger than potential latitude effects (Tables $2-4$ ). The yearly mean values showed that the Swiss and German samples were very similar for all analysed parameters although the PAR values differed greatly. Hence, cv. Clery was less sensitive to environmental changes than cv. Elsanta, which is discussed below and fits to recent studies [10].

Finally, the result indicated that putative impact factors such as origin of plant material, soil composition or precipitation are minor contributors on bioactives compared to the influence of genotype and latitude. Indeed, several earlier studies showed that environmental effects especially cultivation techniques can affect bioactives in fruit significantly [4, 18, 21, 30, 31, 48-50], however, the sampling and year-to-year effect can be in many cases more pronounced than cultivation effects which was predominantly not considered by these studies. The effect of sampling and year is mentioned, but has not yet been evaluated in detail [22, 23, 45].

The above presented results showed the effect of genotype at one location and the one of location for one genotype. In the following the impact of latitude and genotype on bioactives was assessed by analysing two genotypes from two sites (Figs. 6, 7). It was shown that the effect of genotype was stronger than the location effect. Figure 6 showed a PCA of the cvs Korona and Elsanta from Norway and Germany. The cultivar differences were explained by PC1 $(44.34 \%)$ due to variations in the contents of anthocyanins, $p$-coumaroyl glucose, PAC, ascorbic acid, and flavonols. The two cultivars were clearly distinguished, but responded similarly; PC2 $(21.90 \%)$ was mainly responsible for the location effects. The Norwegian samples were located at the positive scale of PC2 and the German ones at the negative scale (Fig. 6) with weak interferences. Antioxidant capacity (TEAC, TP, ORAC), ellagitannins, PAC, and the unknown components were increased in the northern fruit samples (Table 3). Interestingly, the ORAC value was linked to these parameters and, not like described above, responsible for the separation of the two cultivars (Fig. 2). Additionally, sample variation at both sites was comparable regarding the two cultivars and was lower among the German observations (Fig. 6).

A comparison of cvs Clery and Elsanta at the locations Germany and Switzerland was shown in Fig. 7. These two cultivars were, as described above, more similar than the cvs Elsanta and Korona. The cultivar effects were caused by the PC1 as well, but described the data set only by $31.51 \%$, which could be explained by a greater similarity of these two cultivars. Cv. Clery was characterized by higher contents of anthocyanins, ellagic acid derivatives and ellagitannins after hydrolysis, whereas cv. Elsanta showed higher levels of PAC and ascorbic acid. For cv. Elsanta the two sites Germany and Switzerland differed particularly due to antioxidant capacity (TEAC, ORAC, total phenols), p-coumaroyl glucose, and pelargonidin 3-glucoside (Fig. 7, Tables 2, 3).

A recently published review by Jaakola and Hohtola [20] focused on the effect of latitude on flavonoid biosynthesis with the result of an existing lack of knowledge to this topic. Most publications were focused on single effects of light or temperature or different genotypes were compared for different latitudes [2, 25, 34, 38]. An interesting comparison was done during a developmental study at two locations in Italy with the same strawberry genotypes [9]. As a result, the main differences of origin were observed in the contents of proanthocyanidins and flavonols, but in this framework no climate data was considered. Our study showed that bioactives were affected by the location including a strong dependence of temperature. However, the importance of location was clearly less important than the genetic background (Figs. 6, 7). 
Table 2

Anthocyanin levels in three cultivars from three different locations ${ }^{\mathrm{a}}$

\begin{tabular}{|c|c|c|c|c|c|c|c|c|c|}
\hline Origin & Year & Date & $\begin{array}{l}\text { CYA 3-GLU } \\
\left(\mu \mathrm{g} \mathrm{g}^{-1}\right) \\
\end{array}$ & $\begin{array}{l}\text { PEL 3-GLU } \\
\left(\mu \mathrm{g} \mathrm{g}^{-1}\right) \\
\end{array}$ & $\begin{array}{c}\text { PEL 3-RUT } \\
\left(\mu \mathrm{g} \mathrm{g}^{-1}\right) \\
\end{array}$ & $\begin{array}{c}\text { PEL derivative }^{\mathrm{c}} \\
\left(\mu \mathrm{g} \mathrm{g}^{-1}\right)\end{array}$ & $\begin{array}{c}\text { CYA 3-GLU-MAL } \\
\left(\mu \mathrm{g} \mathrm{g}^{-1}\right)\end{array}$ & $\begin{array}{l}\text { PEL 3-GLU-MAL } \\
\left(\mu \mathrm{g} \mathrm{g}^{-1}\right) \\
\end{array}$ & $\begin{array}{l}\text { SUM ANTHO CYANINS } \\
\left(\mu \mathrm{g} \mathrm{g}^{-1}\right) \\
\end{array}$ \\
\hline \multicolumn{10}{|c|}{ cv. Elsanta } \\
\hline \multirow[t]{4}{*}{$\mathrm{N}$} & 2008 & 1 & $9.3 \pm 1.2$ ef & $159.3 \pm 18.8 \mathrm{n}$ & nd & $0.8 \pm 0.1$ lmno & $1.3 \pm 0.5 \mathrm{ijk}$ & $24.7 \pm 4.5 \mathrm{~lm}$ & $195.4 \pm 22.5$ op \\
\hline & & 2 & $8.5 \pm 2.7 \mathrm{fg}$ & $171.2 \pm 18.6 \mathrm{mn}$ & nd & $1.0 \pm 0.1 \mathrm{jlmno}$ & $1.3 \pm 0.9 \mathrm{ijk}$ & $30.2 \pm 3.31$ & $212.2 \pm 21.5$ no \\
\hline & 2009 & 1 & $5.2 \pm 0.8$ ghij & $126.9 \pm 4.5 \mathrm{o}$ & nd & $0.5 \pm 0.1 \mathrm{nop}$ & $0.8 \pm 0.1 \mathrm{kl}$ & $30.3 \pm 2.21$ & $163.6 \pm 5.8 \mathrm{p}$ \\
\hline & & 2 & $2.7 \pm 0.1 \mathrm{jk}$ & $158.8 \pm 19.4 \mathrm{n}$ & nd & $0.6 \pm 0.1 \mathrm{mnop}$ & $1.0 \pm 0.2 \mathrm{jkl}$ & $30.5 \pm 5.11$ & $193.7 \pm 24.6 \mathrm{op}$ \\
\hline \multirow[t]{2}{*}{ Dk } & 2009 & 1 & $8.0 \pm 1.1 \mathrm{fgh}$ & $145.3 \pm 19.1$ no & nd & $0.3 \pm 0.1 \mathrm{p}$ & $0.8 \pm 0.3 \mathrm{kl}$ & $20.5 \pm 3.8 \mathrm{~m}$ & $174.9 \pm 23.0 \mathrm{p}$ \\
\hline & & 2 & $8.9 \pm 0.9 \mathrm{fg}$ & $191.5 \pm 9.1 \mathrm{~lm}$ & nd & $0.4 \pm 0.2 \mathrm{op}$ & $1.0 \pm 0.1 \mathrm{jkl}$ & $28.8 \pm 1.41$ & $230.5 \pm 9.6 \mathrm{n}$ \\
\hline \multirow[t]{4}{*}{$\mathrm{D}$} & 2008 & 1 & $4.9 \pm 0.5$ ghij & $190.1 \pm 7.4 \mathrm{~lm}$ & nd & $1.1 \pm 0.1 \mathrm{ijklmn}$ & $0.4 \pm 0.11$ & $45.3 \pm 8.2 \mathrm{k}$ & $241.9 \pm 15.4 \mathrm{n}$ \\
\hline & & 2 & $9.6 \pm 1.1 \mathrm{ef}$ & $240.8 \pm 2.4$ hij & nd & $1.9 \pm 0.5$ ghi & $3.4 \pm 0.6 \mathrm{ef}$ & $83.7 \pm 1.0 \mathrm{def}$ & $339.4 \pm 3.1$ hijk \\
\hline & 2009 & 1 & $3.7 \pm 0.4 \mathrm{ijk}$ & $187.2 \pm 10.4 \mathrm{~lm}$ & nd & $1.2 \pm 0.2 \mathrm{ijklmn}$ & $0.4 \pm 0.11$ & $51.8 \pm 2.5 \mathrm{ijk}$ & $244.1 \pm 13.2 \mathrm{n}$ \\
\hline & & 2 & $4.4 \pm 0.7$ hijk & $213.4 \pm 32.7 \mathrm{jkl}$ & nd & $1.3 \pm 0.4 \mathrm{ijklm}$ & $0.7 \pm 0.2 \mathrm{kl}$ & $59.8 \pm 2.9 \mathrm{hi}$ & $279.6 \pm 33.7 \mathrm{~m}$ \\
\hline \multirow[t]{4}{*}{$\mathrm{CH}$} & 2008 & 1 & $8.6 \pm 3.3 \mathrm{fg}$ & $231.0 \pm 7.6 \mathrm{ijk}$ & nd & $1.8 \pm 0.3 \mathrm{ghi}$ & $2.5 \pm 0.5 \mathrm{fg}$ & $64.3 \pm 1.8 \mathrm{gh}$ & $308.2 \pm 9.5 \mathrm{klm}$ \\
\hline & & 2 & $13.8 \pm 0.6 \mathrm{~d}$ & $270.8 \pm 10.7 \mathrm{~g}$ & nd & $2.8 \pm 0.1 \mathrm{de}$ & $4.5 \pm 0.1 \mathrm{bcd}$ & $87.0 \pm 3.9 \mathrm{de}$ & $379.0 \pm 15.2 \mathrm{efg}$ \\
\hline & 2009 & 1 & $6.0 \pm 1.3 \mathrm{fghi}$ & $366.8 \pm 10.6 \mathrm{c}$ & nd & $2.3 \pm 0.6 \mathrm{efg}$ & $2.4 \pm 0.6 \mathrm{fg}$ & $80.3 \pm 12.9$ ef & $457.8 \pm 16.7 \mathrm{c}$ \\
\hline & & 2 & $4.2 \pm 0.3 \mathrm{hijk}$ & $242.9 \pm 6.4 \mathrm{hi}$ & nd & $1.5 \pm 0.4$ hijkl & $1.8 \pm 0.1 \mathrm{ghi}$ & $70.1 \pm 1.7 \mathrm{~g}$ & $320.4 \pm 7.7 \mathrm{jkl}$ \\
\hline \multicolumn{10}{|c|}{ cv. Korona } \\
\hline \multirow[t]{4}{*}{$\mathrm{N}$} & 2008 & 1 & $21.3 \pm 0.6 \mathrm{c}$ & $275.1 \pm 10.5 \mathrm{~g}$ & $17.9 \pm 2.5 \mathrm{~b}$ & $1.7 \pm 0.2 \mathrm{ghij}$ & $4.0 \pm 0.6 \mathrm{cde}$ & $49.8 \pm 1.3 \mathrm{jk}$ & $369.9 \pm 9.8 \mathrm{gh}$ \\
\hline & & 2 & $15.9 \pm 0.5 \mathrm{~d}$ & $287.0 \pm 2.1 \mathrm{fg}$ & $15.4 \pm 1.7 \mathrm{~cd}$ & $1.5 \pm 0.8$ hijkl & $3.7 \pm 0.3 \mathrm{de}$ & $51.3 \pm 2.1 \mathrm{ijk}$ & $374.7 \pm 5.8 \mathrm{fgh}$ \\
\hline & 2009 & 1 & $23.1 \pm 3.1 \mathrm{c}$ & $240.3 \pm 14.0$ hij & $19.6 \pm 1.2 \mathrm{~b}$ & $1.1 \pm 0.2 \mathrm{ijklmn}$ & $4.8 \pm 1.6 \mathrm{bc}$ & $65.4 \pm 5.2 \mathrm{gh}$ & $354.4 \pm 25.7$ ghij \\
\hline & & 2 & $12.5 \pm 3.7 \mathrm{de}$ & $221.0 \pm 9.9 \mathrm{ijk}$ & $13.8 \pm 2.5 \mathrm{cde}$ & $1.0 \pm 0.1 \mathrm{jlmno}$ & $3.4 \pm 0.5$ ef & $51.1 \pm 10.1 \mathrm{ijk}$ & $302.8 \pm 35.6 \mathrm{~lm}$ \\
\hline \multirow[t]{2}{*}{$\mathrm{Dk}$} & 2009 & 1 & $15.4 \pm 0.2 \mathrm{~d}$ & $319.9 \pm 7.1 \mathrm{de}$ & $10.7 \pm 0.5 \mathrm{fg}$ & $2.1 \pm 0.2 \mathrm{fgh}$ & nd & $57.5 \pm 1.2 \mathrm{hij}$ & $405.6 \pm 7.2 \mathrm{ef}$ \\
\hline & & 2 & $21.0 \pm 2.1 \mathrm{c}$ & $410.4 \pm 19.8 \mathrm{~b}$ & $12.1 \pm 0.5 \mathrm{ef}$ & $3.8 \pm 0.3 \mathrm{bc}$ & nd & $78.5 \pm 4.8 \mathrm{f}$ & $525.8 \pm 25.5 \mathrm{~b}$ \\
\hline \multirow[t]{4}{*}{$\mathrm{D}$} & 2008 & 1 & $40.9 \pm 6.4 \mathrm{a}$ & $467.2 \pm 8.4 \mathrm{a}$ & $21.8 \pm 1.7 \mathrm{a}$ & $4.7 \pm 1.1 \mathrm{a}$ & $8.2 \pm 1.7 \mathrm{a}$ & $143.6 \pm 1.9 \mathrm{a}$ & $686.4 \pm 13.5 \mathrm{a}$ \\
\hline & & 2 & $36.0 \pm 3.0 \mathrm{~b}$ & $365.6 \pm 6.9 \mathrm{c}$ & $13.6 \pm 1.4 \mathrm{de}$ & $4.2 \pm 0.1 \mathrm{ab}$ & $8.1 \pm 0.5 \mathrm{a}$ & $109.8 \pm 3.9 \mathrm{~b}$ & $537.3 \pm 3.5 \mathrm{~b}$ \\
\hline & 2009 & 1 & $22.6 \pm 2.9 \mathrm{c}$ & $349.5 \pm 25.8 \mathrm{c}$ & $15.8 \pm 2.0 \mathrm{c}$ & $1.5 \pm 0.3$ hijkl & $5.4 \pm 1.5 \mathrm{~b}$ & $113.7 \pm 6.5 b$ & $508.5 \pm 35.7 \mathrm{~b}$ \\
\hline & & 2 & $15.7 \pm 0.8 \mathrm{~d}$ & $307.7 \pm 5.1$ ef & $12.6 \pm 1.0 \mathrm{ef}$ & $1.3 \pm 0.2 \mathrm{ijklm}$ & $4.5 \pm 0.3 \mathrm{bcd}$ & $99.7 \pm 4.5 \mathrm{c}$ & $441.4 \pm 8.9 \mathrm{~cd}$ \\
\hline
\end{tabular}


Table 2

(Continued)

\begin{tabular}{|c|c|c|c|c|c|c|c|c|c|}
\hline Origin & Year & Date & $\begin{array}{l}\text { CYA 3-GLU } \\
\quad\left(\mu \mathrm{g} \mathrm{g}^{-1}\right)\end{array}$ & $\begin{array}{c}\text { PEL 3-GLU } \\
\left(\mu \mathrm{g} \mathrm{g}^{-1}\right) \\
\end{array}$ & $\begin{array}{c}\text { PEL 3-RUT } \\
\left(\mu \mathrm{g} \mathrm{g}^{-1}\right)\end{array}$ & $\begin{array}{l}\text { PEL derivative }^{\mathrm{c}} \\
\left(\mu \mathrm{g} \mathrm{g}^{-1}\right)\end{array}$ & $\begin{array}{c}\text { CYA 3-GLU-MAL } \\
\left(\mu \mathrm{g} \mathrm{g}^{-1}\right) \\
\end{array}$ & $\begin{array}{l}\text { PEL 3-GLU-MAL } \\
\qquad\left(\mu \mathrm{g} \mathrm{g}^{-1}\right) \\
\end{array}$ & $\begin{array}{l}\text { SUM ANTHO CYANINS } \\
\left(\mu \mathrm{g} \mathrm{g}^{-1}\right) \\
\end{array}$ \\
\hline \multicolumn{10}{|c|}{ cv. Clery } \\
\hline \multirow[t]{4}{*}{ D } & 2008 & 1 & $7.3 \pm 0.5$ fghi & $208.1 \pm 7.4 \mathrm{kl}$ & $8.4 \pm 0.2 \mathrm{hi}$ & $1.8 \pm 0.3 \mathrm{ghi}$ & $1.5 \pm 0.2 \mathrm{hijk}$ & $56.9 \pm 1.6 \mathrm{hij}$ & $284.0 \pm 6.9 \mathrm{~m}$ \\
\hline & & 2 & $6.6 \pm 0.9$ fghi & $339.7 \pm 9.1 \mathrm{~cd}$ & $8.9 \pm 3.5 \mathrm{gh}$ & $3.5 \pm 0.3 \mathrm{~cd}$ & $2.5 \pm 0.2 \mathrm{fgh}$ & $90.2 \pm 1.5 \mathrm{~d}$ & $451.4 \pm 25.0 \mathrm{c}$ \\
\hline & 2009 & 1 & $2.3 \pm 0.6 \mathrm{k}$ & $312.0 \pm 14.7 \mathrm{ef}$ & $7.6 \pm 1.6 \mathrm{hij}$ & $1.6 \pm 0.2$ ghijk & $1.1 \pm 0.2 \mathrm{jkl}$ & $88.3 \pm 8.4 \mathrm{de}$ & $412.8 \pm 32.6 \mathrm{de}$ \\
\hline & & 2 & $2.7 \pm 0.1 \mathrm{jk}$ & $262.7 \pm 11.5 \mathrm{gh}$ & $6.7 \pm 0.6 \mathrm{ijk}$ & $1.5 \pm 0.4$ hijkl & $0.8 \pm 0.1 \mathrm{kl}$ & $84.8 \pm 2.4 \mathrm{def}$ & $359.2 \pm 14.3 \mathrm{ghi}$ \\
\hline \multirow[t]{4}{*}{$\mathrm{CH}$} & 2008 & 1 & $6.1 \pm 1.3$ fghi & $266.3 \pm 9.5 \mathrm{gh}$ & $4.9 \pm 1.4 \mathrm{kl}$ & $3.0 \pm 0.8 \mathrm{de}$ & $1.3 \pm 0.1 \mathrm{ijk}$ & $81.3 \pm 6.9 \mathrm{def}$ & $363.9 \pm 20.9 \mathrm{gh}$ \\
\hline & & 2 & $5.0 \pm 1.2 \mathrm{ghij}$ & $285.0 \pm 21.6 \mathrm{fg}$ & $5.3 \pm 0.7 \mathrm{kl}$ & $3.4 \pm 0.6 \mathrm{~cd}$ & $1.0 \pm 0.1 \mathrm{jkl}$ & $81.4 \pm 6.0 \mathrm{def}$ & $382.4 \pm 27.5 \mathrm{efg}$ \\
\hline & 2009 & 1 & $3.5 \pm 0.1 \mathrm{ijk}$ & $366.8 \pm 10.6 \mathrm{c}$ & $6.2 \pm 0.2 \mathrm{jkl}$ & $2.7 \pm 0.2 \mathrm{ef}$ & $0.9 \pm 0.3 \mathrm{jkl}$ & $87.4 \pm 3.6 \mathrm{de}$ & $468.7 \pm 14.7 \mathrm{c}$ \\
\hline & & 2 & $4.2 \pm 0.3 \mathrm{hijk}$ & $242.9 \pm 6.4 \mathrm{hi}$ & $4.2 \pm 0.31$ & $1.5 \pm 0.4 \mathrm{hijkl}$ & $0.9 \pm 0.1 \mathrm{jkl}$ & $70.1 \pm 1.7 \mathrm{~g}$ & $324.7 \pm 8.0 \mathrm{ijkl}$ \\
\hline \multicolumn{10}{|c|}{ Significance } \\
\hline & & Cultivar & $* *$ & $* *$ & $* *$ & $* *$ & $* *$ & $* *$ & $* *$ \\
\hline & & Origin & $* *$ & $* *$ & $* *$ & $* *$ & $* *$ & $* *$ & $* *$ \\
\hline & & Year & $* *$ & $* *$ & $*$ & $* *$ & $* *$ & $\mathrm{~ns}$ & $* *$ \\
\hline & & Sampling & $\mathrm{ns}$ & $\mathrm{ns}$ & $* *$ & $* *$ & $\mathrm{~ns}$ & $* *$ & $* *$ \\
\hline & & Cultivar $\mathrm{x}$ origin & $* *$ & $* *$ & $* *$ & $* *$ & $* *$ & $* *$ & $* *$ \\
\hline & & Cultivar x year & $* *$ & $* *$ & ** & *** & $* *$ & ** & $* *$ \\
\hline
\end{tabular}

${ }^{a}$ Data are expressed as mean of each sampling date. Mean values $(n=3)$ followed by a different lower-case letter in each column were significantly different at $P \leq 0.05$ (Tamhanes test). Data are expressed as equivalents of ${ }^{b}$ cyanidin 3-glucoside and ${ }^{c}$ pelargonidin 3-glucoside. nd, not detected; CYA, cyanidin; PEL, pelargonidin; GLU, glucoside; CYA, cyanidin; GLU-MAL, glucoside-malonate; D, Germany; CH, Switzerland; Dk, Denmark; N, Norway. 
Table 3

Levels of phenolic compounds in three cultivars from three different locations ${ }^{\mathrm{a}}$

\begin{tabular}{|c|c|c|c|c|c|c|c|c|c|}
\hline Origin & Year & Date & $\mathrm{ET}^{\mathrm{b}}\left(\mu \mathrm{g} \mathrm{g}^{-1}\right)$ & $\operatorname{PAC}^{\mathrm{c}}\left(\mu \mathrm{gg}^{-1}\right)$ & $\begin{array}{l}p \text { - COU GLU }{ }^{\mathrm{d}}(\mu \mathrm{g} \\
\left.\mathrm{g}^{-1}\right)\end{array}$ & EA derivative $^{\mathrm{b}}\left(\mu \mathrm{g} \mathrm{g}^{-1}\right)$ & $\begin{array}{l}\text { QUER 3-GLC } \\
\left(\mu \mathrm{g} \mathrm{g}^{-1}\right)\end{array}$ & $\begin{array}{c}\text { KAE 3-GLC+KAE } \\
\text { 3-GLU }\left(\mu \mathrm{g} \mathrm{g}^{-1}\right) \\
\end{array}$ & $\begin{array}{l}\text { KAE 3-GLC-MAL }{ }^{\mathrm{f}} \\
\left(\mu \mathrm{g} \mathrm{g}^{-1}\right)\end{array}$ \\
\hline \multicolumn{10}{|c|}{ cv. Elsanta } \\
\hline \multirow[t]{4}{*}{$\mathrm{N}$} & 2008 & 1 & $455 \pm 65$ defgh & $326 \pm 13 c$ & $17.8 \pm 3.1 \mathrm{ij}$ & $7.2 \pm 1.6 \mathrm{hijk}$ & $32.8 \pm 3.8 \mathrm{abcd}$ & $3.8 \pm 0.4 \mathrm{f}$ & $4.7 \pm 0.6 \mathrm{~d}$ \\
\hline & & 2 & $381 \pm 27 \mathrm{ijk}$ & $249 \pm 24 \mathrm{gh}$ & $18.9 \pm 7.6 \mathrm{hi}$ & $6.5 \pm 1.6 \mathrm{klmn}$ & $28.9 \pm 5.8$ bcde & $6.4 \pm 0.5 \mathrm{~d}$ & $4.5 \pm 0.3 \mathrm{~d}$ \\
\hline & 2009 & 1 & $559 \pm 31 \mathrm{bcd}$ & $401 \pm 8 b$ & $32.3 \pm 3.5$ ef & $6.1 \pm 0.5$ lmno & $28.9 \pm 1.4$ bcde & $5.3 \pm 0.3 \mathrm{e}$ & $4.2 \pm 0.1 \mathrm{de}$ \\
\hline & & 2 & $497 \pm 86 \mathrm{cdef}$ & $278 \pm 28$ efg & $17.6 \pm 3.7 \mathrm{ij}$ & $5.1 \pm 1.6$ nop & $14.6 \pm 2.6 \mathrm{lmn}$ & $4.7 \pm 0.5 \mathrm{e}$ & $4.2 \pm 0.5 \mathrm{de}$ \\
\hline \multirow[t]{2}{*}{$\mathrm{Dk}$} & 2009 & 1 & $449 \pm 25$ defgh & $446 \pm 44 \mathrm{a}$ & $29.8 \pm 0.7 \mathrm{fg}$ & $5.6 \pm 0.5 \mathrm{mnop}$ & $35.9 \pm 6 \mathrm{a}$ & $6.3 \pm 0.8 \mathrm{~d}$ & $3.2 \pm 0.6 \mathrm{efgh}$ \\
\hline & & 2 & $695 \pm 47 \mathrm{ab}$ & $445 \pm 50 \mathrm{a}$ & $35.7 \pm 1.1 \mathrm{de}$ & $6.2 \pm 0.8$ lmno & $35.2 \pm 2.2 \mathrm{ab}$ & $7.2 \pm 0.2 \mathrm{bc}$ & $4.2 \pm 0.7 \mathrm{de}$ \\
\hline \multirow[t]{4}{*}{$\mathrm{D}$} & 2008 & 1 & $389 \pm 17$ ghijk & $290 \pm 7 \mathrm{def}$ & $14.2 \pm 2.3 \mathrm{j}$ & $6.7 \pm 0.5 \mathrm{jklm}$ & $24.8 \pm 1.9 \mathrm{efg}$ & $6.2 \pm 0.5 \mathrm{~d}$ & $6.1 \pm 1.1 \mathrm{c}$ \\
\hline & & 2 & $470 \pm 12$ cdefg & $254 \pm 27 \mathrm{fgh}$ & $16.5 \pm 3.1 \mathrm{ij}$ & $5.5 \pm 0.6 \mathrm{mnop}$ & $29.4 \pm 1.5$ bcde & $8.7 \pm 0.7 \mathrm{a}$ & $8.1 \pm 1.8 \mathrm{a}$ \\
\hline & 2009 & 1 & $351 \pm 21 \mathrm{jk}$ & $274 \pm 13 \mathrm{efgh}$ & $23.2 \pm 0.7 \mathrm{~h}$ & $3.4 \pm 0.2 \mathrm{p}$ & $20.1 \pm 1.0$ ghijkl & $4.8 \pm 0.2 \mathrm{e}$ & $5.8 \pm 0.6 \mathrm{c}$ \\
\hline & & 2 & $502 \pm 169 \mathrm{cdef}$ & $277 \pm 6$ efgh & $18.0 \pm 1.8 \mathrm{hi}$ & $5.4 \pm 0.5$ mnop & $20.3 \pm 2.3$ ghijkl & $7.6 \pm 0.6 \mathrm{~b}$ & $6.1 \pm 1.3 \mathrm{c}$ \\
\hline \multirow[t]{4}{*}{$\mathrm{CH}$} & 2008 & 1 & $349 \pm 59 \mathrm{jk}$ & $261 \pm 22 \mathrm{efgh}$ & $19.4 \pm 2.0 \mathrm{hi}$ & $4.5 \pm 1.3 \mathrm{op}$ & $23.5 \pm 3.5$ efghi & $5.4 \pm 0.4 \mathrm{e}$ & $7.3 \pm 0.8 \mathrm{ab}$ \\
\hline & & 2 & $348 \pm 7 \mathrm{jk}$ & $241 \pm 1 \mathrm{~h}$ & $20.1 \pm 0.9 \mathrm{hi}$ & $5.2 \pm 0.1 \mathrm{nop}$ & $28.8 \pm 1.2$ bcde & $6.6 \pm 0.3 \mathrm{~cd}$ & $6.8 \pm 0.3 \mathrm{bc}$ \\
\hline & 2009 & 1 & $398 \pm 42$ ghij & $292 \pm 8$ de & $32.0 \pm 3.3 \mathrm{ef}$ & $8.0 \pm 1.4 \mathrm{ghij}$ & $27.4 \pm 2.3$ cde & $8.6 \pm 0.2 \mathrm{a}$ & $4.5 \pm 0.3 \mathrm{~d}$ \\
\hline & & 2 & $398 \pm 42$ ghij & $314 \pm 21 \mathrm{~cd}$ & $20.2 \pm 2.1 \mathrm{hi}$ & $6.4 \pm 0.4 \mathrm{klmn}$ & $29.0 \pm 1.7$ bcde & $8.6 \pm 0.8 \mathrm{a}$ & $3.1 \pm 0.3 \mathrm{fgh}$ \\
\hline \multicolumn{10}{|c|}{ cv. Korona } \\
\hline \multirow[t]{4}{*}{$\mathrm{N}$} & 2008 & 1 & $415 \pm 27$ fghij & $181 \pm 36 \mathrm{ijk}$ & $45.5 \pm 5.6 \mathrm{~cd}$ & $8.5 \pm 1.0$ efghi & $15.3 \pm 2.3 \mathrm{klmn}$ & $1.4 \pm 0.2 \mathrm{~g}$ & $1.6 \pm 0.1 \mathrm{jk}$ \\
\hline & & 2 & $321 \pm 53 \mathrm{k}$ & $151 \pm 19 \mathrm{~lm}$ & $41.2 \pm 6.5 \mathrm{~cd}$ & $8.8 \pm 2.4$ efghi & $6.8 \pm 0.7 \mathrm{o}$ & $1.2 \pm 0.1 \mathrm{gh}$ & $1.2 \pm 0.2 \mathrm{k}$ \\
\hline & 2009 & 1 & $646 \pm 104 \mathrm{ab}$ & $255 \pm 6$ efgh & $60.7 \pm 2.2 \mathrm{~b}$ & $11.1 \pm 1.1 \mathrm{cdef}$ & $26.5 \pm 2.2 \mathrm{cdef}$ & $1.0 \pm 0.1 \mathrm{gh}$ & $1.6 \pm 0.1 \mathrm{jk}$ \\
\hline & & 2 & $582 \pm 49 \mathrm{bc}$ & $184 \pm 12 \mathrm{ijk}$ & $44.7 \pm 6.4 \mathrm{~cd}$ & $10.5 \pm 0.4 \mathrm{cdefg}$ & $10.7 \pm 2.4$ no & $0.5 \pm 0.1 \mathrm{~h}$ & $1.2 \pm 0.2 \mathrm{k}$ \\
\hline \multirow[t]{2}{*}{$\mathrm{Dk}$} & 2009 & 1 & $453 \pm 130$ defgh & $191 \pm 8 \mathrm{ijk}$ & $74.3 \pm 4.7 \mathrm{a}$ & $9.5 \pm 1.5$ defgh & $16.6 \pm 1.7 \mathrm{jklm}$ & $0.9 \pm 0.1 \mathrm{gh}$ & $1.4 \pm 0.1 \mathrm{jk}$ \\
\hline & & 2 & $562 \pm 28 \mathrm{bcd}$ & $202 \pm 21$ ijk & $70.6 \pm 4.3 \mathrm{a}$ & $10.1 \pm 5.9 \mathrm{cdefgh}$ & $12.3 \pm 2.4 \mathrm{mn}$ & $0.7 \pm 0.2 \mathrm{gh}$ & $1.6 \pm 0.2 \mathrm{jk}$ \\
\hline \multirow[t]{4}{*}{$\mathrm{D}$} & 2008 & 1 & $531 \pm 50$ cde & $209 \pm 2 \mathrm{i}$ & $33.5 \pm 5.5 \mathrm{ef}$ & $12.0 \pm 2.2 \mathrm{bc}$ & $21.2 \pm 5.1$ fghijk & $1.3 \pm 0.3 \mathrm{gh}$ & $2.6 \pm 0.1 \mathrm{ghi}$ \\
\hline & & 2 & $424 \pm 29$ efghi & $150 \pm 8 \mathrm{~lm}$ & $41.7 \pm 4.8 \mathrm{~cd}$ & $11.1 \pm 1.8 \mathrm{cdef}$ & $22.8 \pm 2.4$ efghij & $0.8 \pm 0.1 \mathrm{gh}$ & $2.3 \pm 0.2 \mathrm{hij}$ \\
\hline & 2009 & 1 & $392 \pm 28$ ghijk & $165 \pm 3 \mathrm{kl}$ & $43.3 \pm 2.0 \mathrm{~cd}$ & $7.0 \pm 0.5 \mathrm{ijklm}$ & $18.0 \pm 2.6$ hijkl & $0.9 \pm 0.1 \mathrm{gh}$ & $2.2 \pm 0.2 \mathrm{hijk}$ \\
\hline & & 2 & $509 \pm 78 \mathrm{cdef}$ & $154 \pm 2 \mathrm{~lm}$ & $40.6 \pm 4.3 \mathrm{~cd}$ & $9.0 \pm 1.2$ defgh & $17.0 \pm 2.1 \mathrm{ijklm}$ & $0.5 \pm 0.1 \mathrm{~h}$ & $1.9 \pm 0.1 \mathrm{ijk}$ \\
\hline
\end{tabular}


Table 3

(Continued)

\begin{tabular}{|c|c|c|c|c|c|c|c|c|c|}
\hline Origin & Year & Date & $\mathrm{ET}^{\mathrm{b}}\left(\mu \mathrm{g} \mathrm{g}^{-1}\right)$ & $\operatorname{PAC}^{\mathrm{c}}\left(\mu \mathrm{g} \mathrm{g}^{-1}\right)$ & $\begin{array}{c}p-\mathrm{COU} \mathrm{GLU}^{\mathrm{d}} \\
\left(\mu \mathrm{g} \mathrm{g}^{-1}\right)\end{array}$ & EA derivative $^{\mathrm{b}}\left(\mu \mathrm{g} \mathrm{g}^{-1}\right)$ & $\begin{array}{c}\text { QUER 3-GLC } \\
\left(\mu \mathrm{g} \mathrm{g}^{-1}\right)\end{array}$ & $\begin{array}{c}\text { KAE 3-GLC+KAE 3-GLU } \\
\left(\mu \mathrm{g} \mathrm{g}^{-1}\right) \\
\end{array}$ & 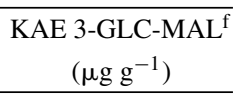 \\
\hline \multicolumn{10}{|c|}{ cv. Clery } \\
\hline \multirow[t]{4}{*}{$\mathrm{D}$} & 2008 & 1 & $536 \pm 37$ bcde & $172 \pm 6 \mathrm{jkl}$ & $17.8 \pm 1.4 \mathrm{ij}$ & $14.4 \pm 1.0 \mathrm{ab}$ & $31.7 \pm 1.9 \mathrm{abcd}$ & $7.4 \pm 0.1 \mathrm{~b}$ & $2.8 \pm 0.2$ fghi \\
\hline & & 2 & $485 \pm 61$ cdefg & $159 \pm 28 \mathrm{kl}$ & $20.9 \pm 0.8 \mathrm{~h}$ & $11.3 \pm 0.4$ cde & $21.8 \pm 2.6$ fghij & $8.5 \pm 0.4 \mathrm{a}$ & $4.2 \pm 0.2 \mathrm{de}$ \\
\hline & 2009 & 1 & $407 \pm 66$ ghij & $179 \pm 10 \mathrm{ijk}$ & $27.2 \pm 1.8 \mathrm{~g}$ & $9.1 \pm 1.7$ defgh & $23.3 \pm 1.7$ efghij & $8.0 \pm 0.4 \mathrm{ab}$ & $4.3 \pm 0.6 \mathrm{~d}$ \\
\hline & & 2 & $476 \pm 58$ cdefg & $149 \pm 9 \operatorname{lm}$ & $16.9 \pm 1.2 \mathrm{ij}$ & $8.2 \pm 1.3$ fghij & $24.3 \pm 3.5$ efgh & $8.6 \pm 0.4 \mathrm{a}$ & $3.1 \pm 0.3 \mathrm{fgh}$ \\
\hline \multirow[t]{4}{*}{$\mathrm{CH}$} & 2008 & 1 & $387 \pm 19$ hijk & $122 \pm 14 \mathrm{~m}$ & $15.7 \pm 2.2 \mathrm{j}$ & $10.8 \pm 1.4$ cdefg & $27.9 \pm 1.7 \mathrm{cde}$ & $7.7 \pm 0.2 \mathrm{~b}$ & $3.6 \pm 0.4 \mathrm{defg}$ \\
\hline & & 2 & $426 \pm 18$ efghi & $121 \pm 4 \mathrm{~m}$ & $23.1 \pm 0.8 \mathrm{~h}$ & $9.2 \pm 1.1 \mathrm{defgh}$ & $26.0 \pm 2.1 \mathrm{def}$ & $7.9 \pm 0.8 \mathrm{ab}$ & $3.8 \pm 0.4 \mathrm{def}$ \\
\hline & 2009 & 1 & $575 \pm 51 \mathrm{bc}$ & $184 \pm 11 \mathrm{ijk}$ & $32.0 \pm 3.3 \mathrm{ef}$ & $16.4 \pm 0.4 \mathrm{a}$ & $27.4 \pm 3.3$ cde & $8.6 \pm 0.2 \mathrm{a}$ & $4.5 \pm 0.3 \mathrm{~d}$ \\
\hline & & 2 & $575 \pm 51 \mathrm{bc}$ & $170 \pm 16 \mathrm{jkl}$ & $18.2 \pm 3.7 \mathrm{hi}$ & $11.8 \pm 0.6 \mathrm{~cd}$ & $33.0 \pm 7.1 \mathrm{abc}$ & $8.6 \pm 0.8 \mathrm{a}$ & $3.1 \pm 0.3 \mathrm{fgh}$ \\
\hline \multicolumn{10}{|c|}{ Significance } \\
\hline & & Cultivar & $* *$ & $* *$ & $* *$ & $* *$ & $* *$ & $* *$ & $* *$ \\
\hline & & Origin & $* *$ & $* *$ & $* *$ & $\mathrm{~ns}$ & $* *$ & $* *$ & $* *$ \\
\hline & & Year & $* *$ & $* *$ & $*$ & $\mathrm{~ns}$ & $\mathrm{~ns}$ & $* *$ & $* *$ \\
\hline & & Sampling & $\mathrm{ns}$ & $* *$ & $* *$ & $*$ & $* *$ & $* *$ & $\mathrm{~ns}$ \\
\hline & & Cultivar $\mathrm{x}$ origin & $* *$ & $* *$ & $* *$ & $\mathrm{~ns}$ & $* *$ & ** & ** \\
\hline & & Cultivar x year & $* *$ & $* *$ & $* *$ & $* *$ & $* *$ & ** & $* *$ \\
\hline
\end{tabular}

${ }^{a}$ Data are expressed as mean of each sampling date. Mean values $(n=3)$ followed by a different lower-case letter in each column were significantly different at $P \leq 0.05$ (Tamhanes test). Data are expressed as equivalents of ${ }^{\mathrm{b}}$ ellagic acid, ${ }^{\mathrm{c}}$ catechin, ${ }^{\mathrm{d}}$ coumaric acid, ${ }^{\mathrm{e}}$ quercetin 3-glucuronide, and ${ }^{\mathrm{f}}$ kaempferol 3-glucuronide in $\mu \mathrm{g} \mathrm{g}{ }^{-1}$ of FW. EA, ellagic acid; PAC, proanthocyanidins. D, Germany; CH, Switzerland; Dk, Denmark; N, Norway. All other abbreviations see legend Fig. 1. 
Table 4

Levels of DM, SSC, TA, AA, TMA, TP, ORAC and TEAC in three cultivars from three different locations ${ }^{\mathrm{a}}$

\begin{tabular}{|c|c|c|c|c|c|c|c|c|c|c|}
\hline Origin & Year & Date & $\mathrm{DM}(\%)$ & SSC (\%) & TA $(\%)$ & AA $\left(\mu \mathrm{g} \mathrm{g}^{-1}\right)$ & TMA $\left(\mu \mathrm{g} \mathrm{g}^{-1}\right)$ & $\mathrm{TP}\left(\mu \mathrm{g} \mathrm{g}^{-1}\right)$ & ORAC $\left(\mu \mathrm{mol} \mathrm{g}^{-1}\right)$ & TEAC $\left(\mu \mathrm{mol} \mathrm{g}^{-1}\right)$ \\
\hline \multicolumn{11}{|c|}{ cv. Elsanta } \\
\hline \multirow[t]{4}{*}{$\mathrm{N}$} & 2008 & 1 & $13.0 \pm 0.8 \mathrm{a}$ & $10.4 \pm 2.3 \mathrm{a}$ & $0.91 \pm 0.04$ bcde & $679 \pm 111$ hijk & $272 \pm 51 \mathrm{q}$ & $2492 \pm 274 \mathrm{bc}$ & $34.3 \pm 2.4$ fghij & $31.6 \pm 2.1 \mathrm{de}$ \\
\hline & & 2 & $11.8 \pm 0.6 \mathrm{~b}$ & $10.2 \pm 1.1 \mathrm{a}$ & $0.91 \pm 0.04$ bcde & $689 \pm 13$ fghij & $278 \pm 22 \mathrm{pq}$ & $2163 \pm 181 \mathrm{defg}$ & $32.2 \pm 1.8$ ghijk & $27.8 \pm 1.9$ fghij \\
\hline & 2009 & 1 & $11.4 \pm 0.4 \mathrm{bc}$ & $10.2 \pm 0.1 \mathrm{a}$ & $0.95 \pm 0.06 \mathrm{abcd}$ & $803 \pm 48$ bcde & $240 \pm 9 \mathrm{q}$ & $2633 \pm 6 b$ & $51.9 \pm 1.5 \mathrm{a}$ & $36.1 \pm 1.4 \mathrm{bc}$ \\
\hline & & 2 & $10.7 \pm 0.3 \mathrm{~cd}$ & $8.8 \pm 0.1 \mathrm{bcd}$ & $1.05 \pm 0.19 \mathrm{a}$ & $798 \pm 20$ bcde & $280 \pm 26 \mathrm{pq}$ & $2037 \pm 123 \mathrm{efgh}$ & $41.5 \pm 5.1 \mathrm{bcd}$ & $28.0 \pm 1.7$ fghij \\
\hline \multirow[t]{2}{*}{$\mathrm{Dk}$} & 2009 & 1 & $10.7 \pm 0.7 \mathrm{~cd}$ & $9.5 \pm 0.1 \mathrm{ab}$ & $0.84 \pm 0.02$ efghi & $853 \pm 35 \mathrm{bc}$ & $266 \pm 30 q$ & $3090 \pm 258 \mathrm{a}$ & $55.2 \pm 1.8 \mathrm{a}$ & $37.7 \pm 2.1 \mathrm{ab}$ \\
\hline & & 2 & $9.4 \pm 1.3$ fghi & $8.2 \pm 0.8 \mathrm{cdef}$ & $0.83 \pm 0.01$ efghi & $978 \pm 63 \mathrm{a}$ & $332 \pm 2$ op & $3209 \pm 234$ a & $56.9 \pm 3.0 \mathrm{a}$ & $40.1 \pm 3.0 \mathrm{a}$ \\
\hline \multirow[t]{4}{*}{$\mathrm{D}$} & 2008 & 1 & $7.1 \pm 0.11$ & $6.0 \pm 0.3 \mathrm{kl}$ & $0.79 \pm 0.02$ fghij & $775 \pm 25$ cdefg & $358 \pm 9$ mno & $2294 \pm 193 \mathrm{cde}$ & $28.0 \pm 3.2 \mathrm{kl}$ & $26.8 \pm 1.8 \mathrm{hijkl}$ \\
\hline & & 2 & $9.8 \pm 0.5 \mathrm{efgh}$ & $8.2 \pm 0.3 \mathrm{cdef}$ & $0.65 \pm 0.2 \mathrm{~lm}$ & $608 \pm 42 \mathrm{klm}$ & $539 \pm 24$ hij & $2085 \pm 118$ defgh & $26.9 \pm 3.4 \mathrm{kl}$ & $23.2 \pm 2.6 \mathrm{nopq}$ \\
\hline & 2009 & 1 & $8.4 \pm 0.4 \mathrm{jk}$ & $6.2 \pm 0.1 \mathrm{jkl}$ & $0.74 \pm 0.03 \mathrm{ijklm}$ & $980 \pm 24 \mathrm{a}$ & $345 \pm 20$ no & $1891 \pm 41$ hijk & $31.8 \pm 2.1$ ghijk & $24.0 \pm 0.4$ lmno \\
\hline & & 2 & $9.4 \pm 0.3$ fghi & $7.0 \pm 0.2$ ghij & $0.71 \pm 0.03 \mathrm{jklm}$ & $849 \pm 40 \mathrm{bc}$ & $389 \pm 54 \mathrm{mno}$ & $1886 \pm 45$ hijk & $30.4 \pm 0.3$ hijk & $23.6 \pm 1.2 \mathrm{mnop}$ \\
\hline \multirow[t]{4}{*}{$\mathrm{CH}$} & 2008 & 1 & $9.0 \pm 0.4 \mathrm{ijk}$ & $7.2 \pm 0.7$ ghij & $0.72 \pm 0.02 \mathrm{ijklm}$ & $815 \pm 107 \mathrm{bcd}$ & $460 \pm 28 \mathrm{kl}$ & $2224 \pm 124 \mathrm{cde}$ & $38.2 \pm 2.6 \mathrm{cdef}$ & $29.0 \pm 2$ efghi \\
\hline & & 2 & $9.8 \pm 0.2 \mathrm{efgh}$ & $8.5 \pm 0.2$ bcde & $0.71 \pm 0.02 \mathrm{jklm}$ & $818 \pm 40 \mathrm{bcd}$ & $512 \pm 6$ hijk & $2195 \pm 28 \mathrm{cdef}$ & $38.8 \pm 0.5$ bcde & $28.6 \pm 0.5$ efghi \\
\hline & 2009 & 1 & $8.3 \pm 0.1 \mathrm{k}$ & $5.8 \pm 0.61$ & $0.76 \pm 0.04$ ghijk & $777 \pm 25$ cdefg & $389 \pm 8 \mathrm{mno}$ & $2313 \pm 90 \mathrm{cde}$ & $38.1 \pm 1.0 \mathrm{cdef}$ & $30.4 \pm 1.9 \mathrm{defg}$ \\
\hline & & 2 & $11.6 \pm 0.5 \mathrm{bc}$ & $8.5 \pm 0.1$ bcde & $0.80 \pm 0.06$ efghi & $792 \pm 6$ bcdef & $381 \pm 9 \mathrm{mno}$ & $2393 \pm 63 \mathrm{bcd}$ & $37.1 \pm 1.2 \mathrm{cdef}$ & $30.4 \pm 1.7 \mathrm{defg}$ \\
\hline \multicolumn{11}{|c|}{ cv. Korona } \\
\hline \multirow[t]{4}{*}{$\mathrm{N}$} & 2008 & 1 & $12.0 \pm 0.1 \mathrm{~b}$ & $10.4 \pm 1.1 \mathrm{a}$ & $0.85 \pm 0.06 \mathrm{defg}$ & $632 \pm 105 \mathrm{ijkl}$ & $404 \pm 92 \mathrm{mn}$ & $2178 \pm 575 \mathrm{defg}$ & $32.4 \pm 4.6$ fghij & $28.2 \pm 5.3$ fghij \\
\hline & & 2 & $10.3 \pm 0.7 \mathrm{def}$ & $9.3 \pm 0.4 \mathrm{abc}$ & $0.80 \pm 0.06$ efghi & $418 \pm 27$ op & $527 \pm 57$ hij & $1641 \pm 153 \mathrm{klm}$ & $25.2 \pm 21$ & $22.0 \pm 1.6 \mathrm{opq}$ \\
\hline & 2009 & 1 & $11.3 \pm 1.1 \mathrm{bc}$ & $10.1 \pm 0.3 \mathrm{a}$ & $0.98 \pm 0.01 \mathrm{abc}$ & $635 \pm 30 \mathrm{ijkl}$ & $486 \pm 42 \mathrm{jk}$ & $2242 \pm 85$ cde & $44.3 \pm 2.2 \mathrm{~b}$ & $33.2 \pm 0.5 \mathrm{~cd}$ \\
\hline & & 2 & $11.9 \pm 1.1 \mathrm{~b}$ & $10.3 \pm 0.9 \mathrm{a}$ & $0.99 \pm 0.21 \mathrm{ab}$ & $629 \pm 55 \mathrm{jklm}$ & $412 \pm 50 \mathrm{~lm}$ & $1824 \pm 53 \mathrm{ijkl}$ & $39.3 \pm 2.5$ bcde & $26.7 \pm 1.0$ hijkl \\
\hline \multirow[t]{2}{*}{ Dk } & 2009 & 1 & $9.7 \pm 0.2 \mathrm{efgh}$ & $9.0 \pm 0.4 \mathrm{bcd}$ & $0.95 \pm 0.05 \mathrm{abcd}$ & $586 \pm 41 \mathrm{lmn}$ & $566 \pm 16$ fgh & $1987 \pm 152$ fghij & $38.7 \pm 1.7$ bcde & $28.2 \pm 1.4$ fghij \\
\hline & & 2 & $9.9 \pm 0.2 \mathrm{defg}$ & $8.0 \pm 0.2 \mathrm{defg}$ & $0.87 \pm 0.02$ cdef & $468 \pm 25$ no & $730 \pm 15 b$ & $2150 \pm 44$ defg & $42.4 \pm 2.4 \mathrm{bc}$ & $30.6 \pm 1.7 \mathrm{def}$ \\
\hline \multirow[t]{4}{*}{ D } & 2008 & 1 & $7.3 \pm 0.11$ & $6.6 \pm 0.4 \mathrm{ijkl}$ & $0.84 \pm 0.02 \mathrm{efgh}$ & $491 \pm 14$ mno & $881 \pm 7 \mathrm{a}$ & $2011 \pm 113$ efghi & $32.4 \pm 2.4$ ghijk & $25.1 \pm 1.1 \mathrm{jklmn}$ \\
\hline & & 2 & $9.5 \pm 0.3 \mathrm{efgh}$ & $8.2 \pm 0.3$ cdef & $0.74 \pm 0.02 \mathrm{ijklm}$ & $365 \pm 17 \mathrm{p}$ & $692 \pm 6 \mathrm{bc}$ & $1560 \pm 140 \mathrm{~lm}$ & $35.5 \pm 1$ efgh & $21.4 \pm 1.3 \mathrm{pq}$ \\
\hline & 2009 & 1 & $9.0 \pm 0.4 \mathrm{ijk}$ & $6.8 \pm 0.1 \mathrm{ijkl}$ & $0.77 \pm 0.02$ ghijk & $592 \pm 63 \mathrm{klmn}$ & $726 \pm 21 b$ & $1574 \pm 36 \mathrm{~lm}$ & $35.7 \pm 2 \mathrm{defg}$ & $22.9 \pm 0.9$ nopq \\
\hline & & 2 & $9.6 \pm 0.5$ efgh & $7.3 \pm 0.1$ fghij & $0.75 \pm 0.03$ hijkl & $585 \pm 35 \mathrm{lmn}$ & $612 \pm 18 \mathrm{def}$ & $1526 \pm 129 \mathrm{~m}$ & $35.8 \pm 2.5 \mathrm{defg}$ & $22.2 \pm 1.1 \mathrm{opq}$ \\
\hline
\end{tabular}


Table 4

(Continued)

\begin{tabular}{|c|c|c|c|c|c|c|c|c|c|c|}
\hline Origin & Year & Date & $\mathrm{DM}(\%)$ & $\operatorname{SSC}(\%)$ & $\mathrm{TA}(\%)$ & $\mathrm{AA}\left(\mu \mathrm{g} \mathrm{g}^{-1}\right)$ & TMA $\left(\mu \mathrm{g} \mathrm{g}^{-1}\right)$ & $\mathrm{TP}\left(\mu \mathrm{g} \mathrm{g}^{-1}\right)$ & ORAC $\left(\mu \mathrm{mol} \mathrm{g}^{-1}\right)$ & TEAC $\left(\mu \mathrm{mol} \mathrm{g}^{-1}\right)$ \\
\hline \multicolumn{11}{|c|}{ cv. Clery } \\
\hline \multirow[t]{4}{*}{ D } & 2008 & 1 & $9.8 \pm 0.2 \mathrm{efgh}$ & $7.5 \pm 0.4 \mathrm{efgh}$ & $0.78 \pm 0.06$ ghijk & $546 \pm 35 \mathrm{mn}$ & $388 \pm 13 \mathrm{mno}$ & $1996 \pm 164$ efghi & $28.7 \pm 1.7 \mathrm{jkl}$ & $23.3 \pm 1.8 \mathrm{nopq}$ \\
\hline & & 2 & $9.3 \pm 0.3$ ghij & $8.4 \pm 0.3$ bcde & $0.68 \pm 0.03 \mathrm{klm}$ & $614 \pm 35 \mathrm{klm}$ & $646 \pm 25$ cde & $1817 \pm 182 \mathrm{ijkl}$ & $26.5 \pm 5.4 \mathrm{kl}$ & $20.8 \pm 2.0 \mathrm{q}$ \\
\hline & 2009 & 1 & $8.9 \pm 0.2 \mathrm{ijk}$ & $7.4 \pm 0.3$ fghi & $0.68 \pm 0.02 \mathrm{klm}$ & $752 \pm 11$ cdefg & $597 \pm 57 \mathrm{efg}$ & $1844 \pm 35 \mathrm{ijkl}$ & $35.7 \pm 2.6 \mathrm{defg}$ & $25.6 \pm 0.6 \mathrm{jklmn}$ \\
\hline & & 2 & $10.4 \pm 0.2 \mathrm{de}$ & $8.6 \pm 0.1 \mathrm{bcde}$ & $0.75 \pm 0.03$ hijkl & $697 \pm 22$ efghi & $505 \pm 16 \mathrm{ijk}$ & $1771 \pm 79 \mathrm{jklm}$ & $35.9 \pm 3.1 \mathrm{defg}$ & $24.6 \pm 1.31 \mathrm{lmno}$ \\
\hline \multirow[t]{4}{*}{$\mathrm{CH}$} & 2008 & 1 & $9.3 \pm 0.4 \mathrm{ghij}$ & $7.3 \pm 0.7$ fghij & $0.64 \pm 0.01 \mathrm{~m}$ & $730 \pm 38$ defgh & $515 \pm 25$ hijk & $1711 \pm 76 \mathrm{jklm}$ & $29.4 \pm 1.2 \mathrm{ijkl}$ & $25.1 \pm 0.9 \mathrm{jklmn}$ \\
\hline & & 2 & $9.9 \pm 0.5 \mathrm{defg}$ & $8.1 \pm 0.4$ defg & $0.71 \pm 0.02 \mathrm{jklm}$ & $887 \pm 17 \mathrm{ab}$ & $551 \pm 21 \mathrm{ghi}$ & $1787 \pm 46 \mathrm{jklm}$ & $30.1 \pm 0.9$ hijk & $23.2 \pm 0.5 \mathrm{nopq}$ \\
\hline & 2009 & 1 & $9.1 \pm 0.1$ hijk & $7.2 \pm 0.5 \mathrm{ghij}$ & $0.64 \pm 0.06 \mathrm{~m}$ & $845 \pm 47 \mathrm{bc}$ & $659 \pm 18 \mathrm{~cd}$ & $2211 \pm 82 \mathrm{cde}$ & $35.3 \pm 1.2 \mathrm{efgh}$ & $29.9 \pm 0.7 \mathrm{efgh}$ \\
\hline & & 2 & $10.4 \pm 0.3 \mathrm{de}$ & $8.2 \pm 0.1 \mathrm{cdef}$ & $0.71 \pm 0.04 \mathrm{jklm}$ & $736 \pm 26 \mathrm{defg}$ & $465 \pm 6 \mathrm{kl}$ & $1984 \pm 69$ fghij & $28.4 \pm 1.2 \mathrm{jkl}$ & $27.0 \pm 0.5 \mathrm{ghijk}$ \\
\hline
\end{tabular}

Significance

\begin{tabular}{|c|c|c|c|c|c|c|c|c|}
\hline Cultivar & $* *$ & ** & $*$ & $* *$ & ** & $* *$ & ** & ** \\
\hline Origin & $* *$ & $* *$ & $* *$ & $* *$ & $* *$ & $* *$ & ** & $* *$ \\
\hline Year & $\mathrm{ns}$ & $\mathrm{ns}$ & $* *$ & $* *$ & $* *$ & ns & ** & ** \\
\hline Sampling & $* *$ & $*$ & $\mathrm{~ns}$ & $* *$ & $* *$ & $* *$ & $*$ & $* *$ \\
\hline Cultivar $\times$ origin & $* *$ & $*$ & $* *$ & $* *$ & $* *$ & $* *$ & ** & ** \\
\hline Cultivar $\times$ year & $* *$ & $*$ & $\mathrm{~ns}$ & $\mathrm{~ns}$ & $* *$ & ns & * & ** \\
\hline
\end{tabular}

${ }^{a}$ Data are expressed as mean of each sampling date. Mean values $(n=3)$ followed by a different lower-case letter in each column were significantly different at $P \leq 0.05$ (Tamhanes test). DM,

Dry matter; SSC, soluble solids content; TA, total acidity; AA, ascorbic acid; TMA, total monomeric anthocyanins as equivalents of pelargonidin 3-glucoside; TP, total phenolics, as gallic acid equivalents; TEAC, trolox equivalent antioxidant capacity as trolox equivalents; ORAC, oxygen radical absobance capacity as trolox equivalents. D, Germany; CH, Switzerland; Dk, Denmark; $\mathrm{N}$, Norway. 

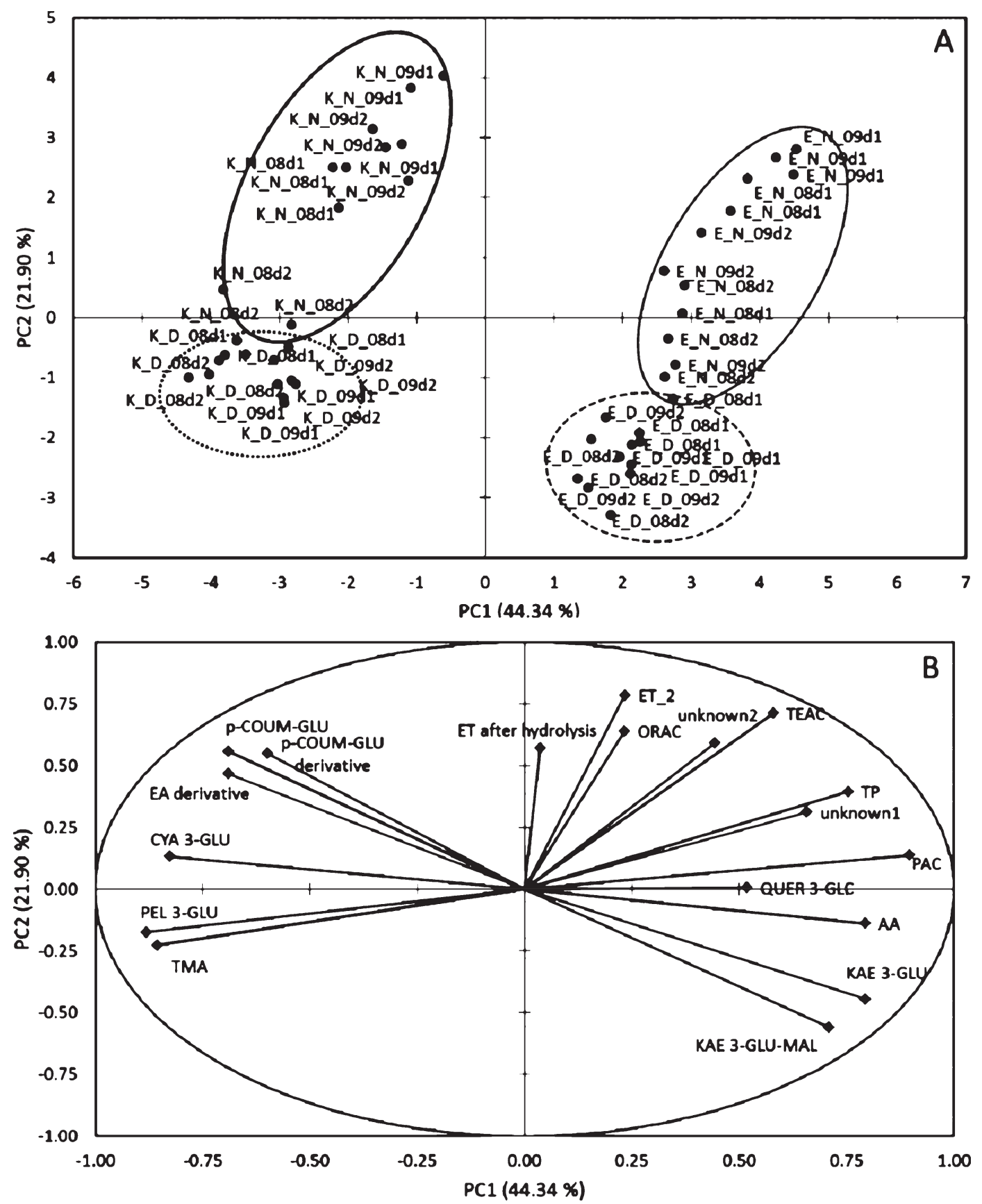

Fig. 6. Principal component analysis (PC1 and PC2) of two cultivars (K= Korona. $\mathrm{E}=$ Elsanta) grown at two locations (D, Germany; N, Norway) displayed in the score plot (A) characterized by bioactive components shown in the loading plot (B). Kaempferol 3-glucoside includes kaempferol 3-glucuronide. The number indicates the experimental year 08 for 2008 and 09 for 2009 . The ending _d 1 indicates the sampling during the harvest period in week 1 and _d2 the sampling in week 2 of the harvest period. 

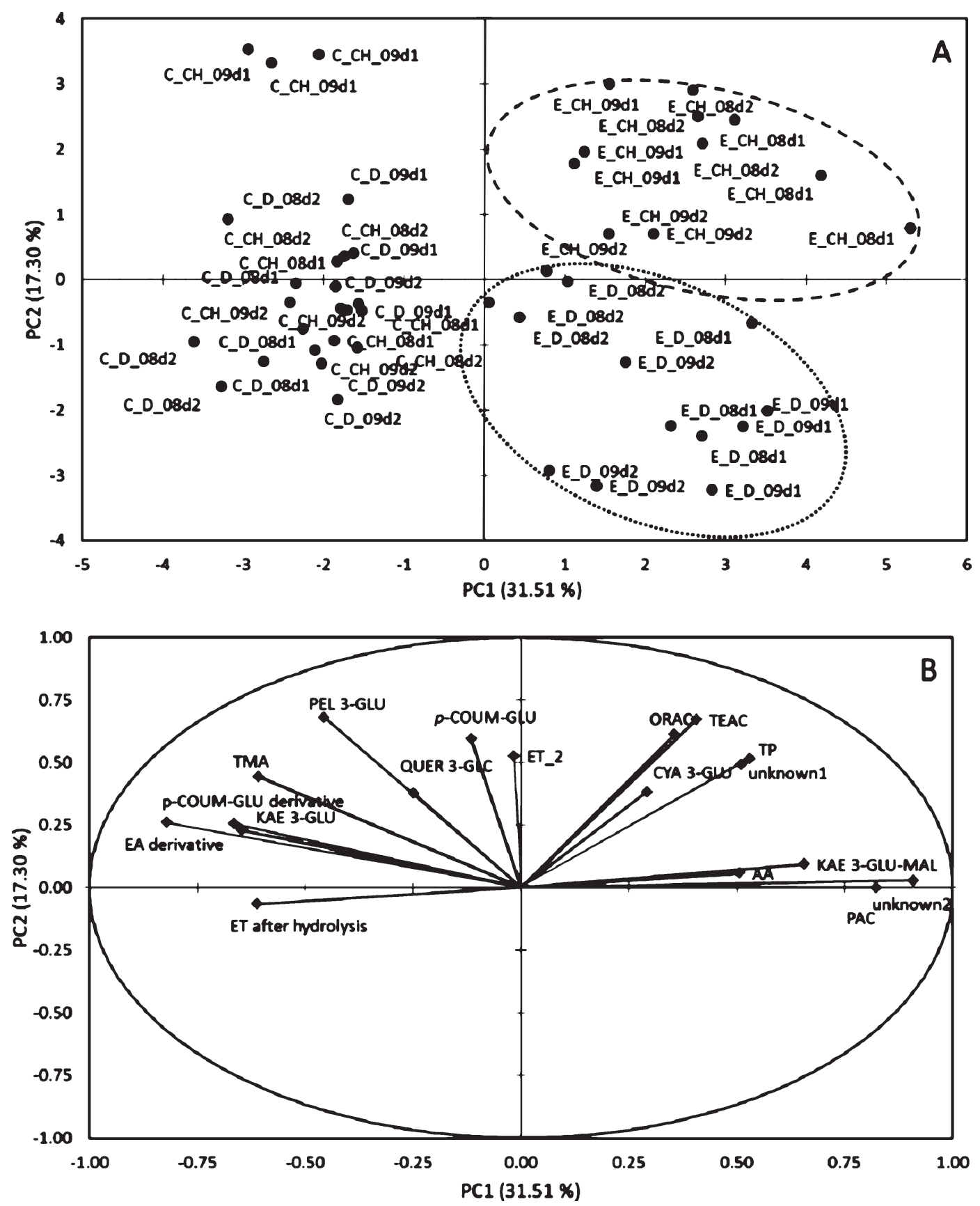

Fig. 7. Principal component analysis ( $\mathrm{PC} 1$ and $\mathrm{PC} 2)$ of two cultivars $(\mathrm{C}=$ Clery. $\mathrm{E}=$ Elsanta) grown at two locations (D, Germany; $\mathrm{CH}$, Switzerland) displayed in the score plot (A) characterized by bioactive components shown in the loading plot (B). Kaempferol 3-glucoside includes kaempferol 3-glucuronide. The number indicates the experimental year 08 for 2008 and 09 for 2009 . The ending _d 1 indicates the sampling during the harvest period in week 1 and _d2 the sampling in week 2 of the harvest period. 
In general, cultivars responded similarly, but displayed different sensitivity to environmental parameters as shown for cv. Clery. A lower content of total anthocyanin in the northern fruit samples was observed as an overall cultivar effect (Table 2). This result could be due to lower mean temperatures in the northern regions (Fig. 3, Table 1). In contrast to other crops [43], strawberry anthocyanins increase with higher temperature [21, 49]. Additionally, the extended day length in the northern regions played a minor role in the biosynthesis of anthocyanins in strawberries. This fact is in agreement with similar studies in respect to protected cultivation and UV-B radiation [22, 32]. Nevertheless, information about effects of photoperiod on anthocyanin biosynthesis in strawberry is still scarce. The biosynthesis of kaempferols is induced by higher temperatures during ripening as well [21, 49], in general, this flavonol was accumulated in fruit from southern regions (Figs. 4, 5, Table 3). Furthermore, Wang et al. [49] found also a high relationship between temperature and the quercetin 3 -glucuronide content. This observation could not be confirmed by the present study because in most cases the level in the fruit was not dependent by the origin (Figs. 4, 5, Table 3). However, the content of this flavonol is also highly dependent on UV-B radiation [22], which could be a possible explanation of the results. A measurement of the UV-B radiation during such a trial would be helpful to elucidate this possibility.

Additionally, northern samples tended to an increased antioxidant capacity despite of low anthocyanin contents. Generally, the tannin-related components like PACs and ellagitannins were increased in the northern fruit samples. This result is conflicting with studies of temperature effects conducted recently [21]: strawberries produced in a cooler environment contained lower contents of PAC and ellagic acid after hydrolysis. During this study, the different temperature treatments were applied with the beginning of flowering. In the present study the higher contents of PAC and ellagitannins in fruit from the northern samples compared to the southern ones can be explained with the extended day length and different temperature profiles during the day. In consideration of the above mentioned greenhouse experiments, the daily temperature profiles of these experiments (day/night: $16^{\circ} \mathrm{C} / 10^{\circ} \mathrm{C}$ and $22^{\circ} \mathrm{C} / 16^{\circ} \mathrm{C}$ ) were not comparable with those of the natural climates of the different locations in the present study (Table 1). A second assumption can be argued by temperature effects during flower emergence. This is supported by a recent developmental and environmental study of strawberry flavonoids [9] where tannin-related bioactives occur in the fruit very early in high contents. A significant effect of the two sites within Italy was observed in the proanthocyanidin composition. More precisely, the epicatechin/catechin ratio was affected by the growing location during the whole ripening process; starting from small green to full ripe fruit. In contrast, no clear effects were observed in ellagic acid related components. A possible explanation could be the distance of the two locations, which was only approximately $4^{\circ}$ of latitude. Within the presented study, the investigations were focused on a comparison of sum parameters of ellagitannins and PAC content. Anyway, a detailed characterization of these compounds would be remarkable. Tannin-related components are often a disregarded class of polyphenols in strawberry studies [4, 49], likely, because of missing analytical methods, although they strongly contribute to the antioxidant capacity [7] and have putative health effects [29, 39]. Within our study PAC showed the highest correlation coefficient of 0.817 with TP which was the highest of all determined parameters.

Significant temperature effects on the content of ascorbic acid in crops were detected in earlier studies with a positive influence of low temperature [21, 27, 37, 47]. In addition, shading affected negatively the ascorbic acid content in strawberries [17]. The results in the present study have shown that the ascorbic acid content in strawberries was increased depending on cooler regions with extended day length (Figs. 4, 5), however with only marginal effects (Table 4).

Besides bioactives, the quality attributes dry matter, soluble solids content, and titratable acidity varied between the origins (Table 4). The presented results were discussed on a fresh weight basis; however, a calculation based on the dry matter content as reference parameter is possible, too and would decrease the contents in the fruit of the northern regions due to lower water contents (Table 4). In addition, not only dry matter should be considered, also the fruit size should be attended. The major content of phenols is located in the peel of the fruit [22]. Hence, the larger the fruit the lower is the surface to flesh ratio. Consequently, the total phenol content is higher in smaller strawberries agreeing to other publications $[4,31]$. Investigations of temperature showed an increase of fruit size with cooler temperatures, which is possibly depending on the cultivar [21, 26, 47], but not directly linked to the growing location [24].

\subsubsection{Effects of latitude on the anthocyanin distribution}

As described above, total anthocyanin content was strongly affected by the growing location, but also the relative distribution of individual anthocyanins was influenced. Generally, cv. Elsanta fruit from the northern locations 
had with about $82 \%$ a higher fraction of pelargonidin 3-glucoside and with $14 \%$ a lower percentage of pelargonidin 3-malonylglucoside than the southern ones (pelargonidin 3-glucoside: 75\%, pelargonidin 3-malonylglucoside: $21 \%$ ). This observation is as well valid for cv. Korona with similar values. The strong influence on pelargonidin 3-malonylglucoside by latitude may be explained by temperature effects; other studies showed that the formation of this pelargonidin derivative is the most temperature inducible anthocyanin in strawberry [21, 22, 49]. Additionally, for cv. Elsanta the percentage of cyanidin 3-glucoside was significantly enhanced for the northern samples compared to the southern ones, although this anthocyanin can be influenced by temperature positively [49]. The absolute amount of cyanidin 3-glucoside was significantly enhanced only in 2008 for cv. Korona in Germany. Similar contents depending on different latitudes may be explained by similar UV-B response as describes above for the content of the flavonol quercetin [22] e.g. the extended day length. The anthocyanin composition of cvs Elsanta and Clery samples from Germany and Switzerland was very similarly, however, the pelargonidin 3-rutinoside fraction in cv. Clery was higher in the German samples (Table 2). Both locations showed low differences in temperature during ripening, whereas PAR was different (Table 1). This result indicated that PAR contributed less to the anthocyanin composition compared to temperature.

\section{Conclusion}

This evaluation showed that genotype was the major contributor to composition of bioactive components in strawberries. However, the growing location affected the content of phenolic components and ascorbic acid as well. In general, the effect of north-south locations (17 degree of latitude) was stronger than year-to-year differences or the effect of harvest period. Other factors, e.g. soil type, precipitation or irrigation seemed to play a less important role than temperature or day length. Furthermore, the effect of temperature is presumably stronger than the impact of light. This assumption is consistent regarding the content of anthocyanins, studied earlier. The hypothesis that northern latitudes might tend to lower content of bioactive compounds was rejected. A strong effect was observed on increased tannin-related components resulting in higher antioxidant capacity in samples from the north but the putative impact factors were difficult to evaluate. In this context further research is necessary with standardised experimental design including samples during the maturation with respect to yield, fruit size and leaf to fruit ratio. This study showed that short-term weather changes can have a high impact on the biosynthesis of bioactives and it is essential to clarify the most susceptible developmental state of the fruit for each class of flavonoids or even flowers where secondary metabolites already occur [15].

\section{Acknowledgments}

The authors acknowledge the European Science Foundation (EU-COST project 863 Euroberry) for supporting the cooperation network of the authors. We like to thank the involved persons from all sites for field and analytical assistance.

\section{References}

[1] K. Aaby, D. Ekeberg and G. Skrede, Characterization of phenolic compounds in strawberry (Fragaria x ananassa) fruits by different HPLC detectors and contribution of individual compounds to total antioxidant capacity, Journal of Agricultural and Food Chemistry 55 (2007), 4395-4406.

[2] A. Åkerström, L. Jaakola, U. Bång and A. Jäderund, Effects of latitude-related factors and geographical origin on anthocyanidin concentrations in fruits of Vaccinium myrtillus L. (bilberries), Journal of Agricultural and Food Chemistry (2010), 11939-11945.

[3] AMI, Marktbilanz Obst: Daten, Fakten, Entwicklung: Deutschland, EU, Welt, Agrarmarkt Informations-Gesellschaft mbH, 2010.

[4] M.J. Anttonen, K.I. Hoppula, R. Nestby, M.J. Verheul and R.O. Karjalainen, Influence of fertilization, mulch color, early forcing, fruit order, planting date, shading, growing environment, and genotype on the contents of selected phenolics in strawberry (Fragaria $\mathrm{x}$ ananassa Duch.) fruits, Journal of Agricultural and Food Chemistry 54 (2006), 2614-2620. 
[5] C.J. Atkinson, P.A.A. Dodds, Y.Y. Ford, J. Le Miere, J.M. Taylor, P.S. Blake and N. Paul, Effects of cultivar, fruit number and reflected photosynthetically active radiation on Fragaria x ananassa productivity and fruit ellagic acid and ascorbic acid concentrations, Annals of Botany 97 (2006), 429-441.

[6] R. Ballentine, Determination of ascorbic acid in citrus fruit juices, Industrial \& Engineering Chemistry Analytical Edition 13 (1941), 89.

[7] G. Borges, A. Degeneve, W. Mullen and A. Crozier, Identification of flavonoid and phenolic antioxidants in black currants, blueberries, raspberries, red currants, and cranberries, Journal of Agricultural and Food Chemistry 58 (2009), 3901-3909.

[8] B. Buendía, M.I. Gil, J.A. Tudela, A.L. Gady, J.J. Medina, C. Soria, J.M. López and F.A. Tomás-Barberán, HPLC-MS analysis of proanthocyanidin oligomers and other phenolics in 15 strawberry cultivars, Journal of Agricultural and Food Chemistry $\mathbf{5 8}$ (2010), 3916-3926.

[9] C. Carbone, A. Preuss, R.C.H. De Vos, E. D’Amico, G. Perrotta, A.G. Bovy, S. Martens and C. Rosati, Developmental, genetic and environmental factors affect the expression of flavonoid genes, enzymes and metabolites in strawberry fruits, Plant, Cell \& Biology 32 (2009), 1117-1131.

[10] P. Crespo, Variability of health and taste promoting compounds in strawberry (Fragaria x ananassa Duch.) fruits, Dissertation, ETH No.19164, 2010.

[11] P. Crespo, J.G. Bordonaba, L.A. Terry and C. Carlen, Characterisation of major taste and health-related compounds of four strawberry genotypes grown at different Swiss production sites, Food Chemistry 122 (2010), 16-24.

[12] M.M. Giusti, L.E. Rodriguez-Saona and R.E. Wrolstad, Molar absorptivity and color characteristics of acylated and non-acylated pelargonidin-based anthocyanins, Journal of Agricultural and Food Chemistry 47 (1999), 4631-4637.

[13] S.H. Häkkinen, H.M. Mykkanen, I.M. Heinonen and A.R. Törrönen, Ellagic acid content in berries: Influence of domestic processing and storage, European Food Research and Technology 212 (2000), 75-80.

[14] J.F. Hancock, Strawberries - Crop Production Science in Horticulture CABI Publishing, 1999.

[15] K. Hanhineva, I. Rogachev, H.I. Kokko, S. Mintz-Oron, I. Venger, S. Kärenlampi and A. Aharoni, Non-targeted analysis of spatial metabolite composition in strawberry (Fragaria x ananassa) flowers, Phytochemistry 69 (2008), 2463-2481.

[16] S.M. Hannum, Potential impact of strawberries on human health: A review of the science, Critical Reviews in Food Science and Nutrition 44 (2004), 1-17.

[17] E. Hansen and G.F. Waldo, Ascorbic acid content of small fruits in relation to genetic and environmental factors, Food Research 9 (1944), 453-461.

[18] D. Hernanz, A.F. Recamales, A.J. Meléndez-Martínez;, M.L. Gonzalez-Miret and F.J. Heredia, Assessment of the differences in the phenolic composition of five strawberry cultivars (Fragaria x ananassa Duch.) grown in two different soilless systems, Journal of Agricultural and Food Chemistry 55 (2007), 1846-1852.

[19] D. Huang, B. Ou, M. Hampsch-Woodill, J.A. Flanagan and R.L.R. Prior, High-throughput assay of oxygen radical absorbance capacity (ORAC) using a multichannel liquid handling system coupled with a microplate fluorescence reader in 96-well format, Journal of Agricultural and Food Chemistry 50 (2002), 4437-4444.

[20] L. Jaakola and A. Hohtola, Effect of latitude on flavonoid biosynthesis in plants, Plant, Cell \& Environment 33 (2010), 1239-1247.

[21] M. Josuttis, H. Dietrich, C.D. Patz and E. Krüger, Effects of air and soil temperatures on the chemical composition of fruit and agronomic performance in strawberry (Fragaria x ananassa Duch.), Journal of Horticultural Science \& Biotechnology 86 (2011), 415-421.

[22] M. Josuttis, H. Dietrich, D. Treutter, F. Will, L. Linnemannstöns and E. Krüger, Solar UVB response of bioactives in strawberry (Fragaria $\mathrm{x}$ ananassa Duch. L.): A comparison of protected and open-field cultivation, Journal of Agricultural and Food Chemistry $\mathbf{5 8}$ (2010), 12692-12702.

[23] M. Josuttis, E. Krüger and H. Dietrich, Influence of cultivation techniques on health beneficial components in strawberry, Acta Hort (ISHS) 838 (2009), 205-206.

[24] E. Krüger, R. Nestby, T.B. Toldam-Andersen, C. Carlen and B. Mezzetti, A comparison of growing condition, strawberry growth and yield performance affected by different latitude of Europe, Journal of Berry Research 2 (2012), (in press).

[25] A.K. Lätti, L. Jaakola, K.R. Riihinen and P.S. Kainulainen, Anthocyanin and flavonol variation in bog bilberries (Vaccinium uliginosum L.) in Finland, Journal of Agricultural and Food Chemistry 58 (2010), 427-433.

[26] J. Le Mière, P. Hadley, J. Darby and N.H. Battey, The effect of thermal environment planting date and crown size on growth development yield of Fragaria x ananassa Duch. cv. Elsanta, Journal of Horticultural Science \& Biotechnology 73 (1998), $786-795$.

[27] S.K. Lee and A.A. Kader, Preharvest and postharvest factors influencing vitamin C content of horticultural crops, Postharvest Biology and Technology 20 (2000), 207-220.

[28] R. Matissek and G. Steiner, Lebensmittelanalytik - Grundzüge, Methoden, Anwendungen Springer-Verlag, Berlin Heidelberg, New York, 2006.

[29] G.J. McDougall, F. Shpiro, P. Dobson, P. Smith, A. Blake and D. Stewart, Different polyphenolic components of soft fruits inhibit $\alpha$-amylase and $\alpha$-glucosidase, Journal of Agricultural and Food Chemistry 53 (2005), 2760-2766.

[30] U. Moor, K. Karp, P. Poldma and A. Pae, Cultural systems affect content of anthocyanins and vitamin C in strawberry fruits, European Journal of Horticultural Science 70 (2005), 195-201.

[31] R. Nestby, M.J. Anttonen, M.J. Verheul and R.O. Karjalainen, Effect of fruit order, polyethylene mulch colour and early forcing on the fruit quality of tunnel-grown strawberry cv. 'Korona', European Journal of Horticultural Science 72 (2011), 164-170. 
[32] M. Ordidge, P. García-Marcías, N.H. Battey, M.H. Gordon, P. Hadley, P. John, J.A. Lovegove, E. Vysini and A. Wagstaffe, Phenolic contents of lettuce, strawberry, raspberry, and blueberry crops cultivated under plastic films varying in ultraviolet transparency, Food Chemistry 119 (2010), 1224-1227.

[33] B. Ou, M. Hampsch-Woodill and R.L.R. Prior, Development and validation of an improved oxygen radical absorbance capacity assay using fluorescein as the fluorescent probe, Journal of Agricultural and Food Chemistry 49 (2001), 4619-4626.

[34] F. Poiroux-Gonord, L.P.R. Bidel, A.L. Fanciullino, H. Gautier, F. Lauri-Lopez and L. Urban, Health benefits of vitamins and secondary metabolites of fruits and vegetables and prospects to increase their concentrations by agronomic approaches, Journal of Agricultural and Food Chemistry $\mathbf{5 8}$ (2010), 12065-12082.

[35] R.L. Prior, E. Fan, H. Ji, A. Howell, C. Nio, M.J. Payne and J. Reed, Multi-laboratory validation of a standard method for quantifying proanthocyanidins in cranberry powders, Journal of the Science of Food and Agriculture 90 (2010), 1473-1478.

[36] R. Re, N. Pellegrini, A. Proteggente, A. Pannala, M. Yang and C. Rice-Evans, Antioxidant activity applying an improved ABTS radical cation decolorization assay, Free Radical Biology and Medicine 26 (1999), 1231-1237.

[37] S.F. Remberg, A. Sønsteby, K. Aaby and O.M. Heide, Influence of postflowering temperature on fruit size and chemical composition of glen ample raspberry (Rubus idaeus L.), Journal of Agricultural and Food Chemistry 58 (2010), 9120-9128.

[38] J. Reyes-Carmona, G.G. Yousef, R.A. Martínez-Peniche and M.A. Lila, Antioxidant capacity of fruit extracts of blackberry (Rubus sp.) produced in different climatic regions, Journal of Food Science 70 (2005), 497-503.

[39] H.A. Ross, G.J. McDougall and D. Stewart, Antiproliferative activity is predominantly associated with ellagitannins in raspberry extracts, Phytochemistry 68 (2007), 218-228.

[40] J. Scalzo, A. Politi, N. Pellegrini, B. Mezzetti and M. Battino, Plant genotype affects total antioxidant capacity and phenolic contents in fruit, Nutrition 21 (2005), 207-213.

[41] N.P. Seeram, Berry fruits for cancer prevention: Current status and future prospects, Journal of Agricultural and Food Chemistry 56 (2008), 630-635.

[42] V.L. Singleton, R. Orthofer and R.M. Lamuela-Raventós, In: Analysis of total phenols and other oxidation substrates and antioxidants by means of Folin-Ciocalteu reagent, ed. P. Lester, Methods in Enzymology Oxidants and Antioxidants Part A (Academic Press), 1999, pp. $152-178$.

[43] D. Treutter, Managing phenol contents in crop plants by phytochemical farming breeding - visions constraints, International Journal of Molecular Sciences 11 (2010), 807-857.

[44] S. Tulipani, B. Mezzetti, F. Capocasa, S. Bompadre, J. Beekwilder, C.H.R. de Vos, E. Capanoglu, A.G. Bovy and M. Battino, Antioxidants, phenolic compounds, and nutritional quality of different strawberry genotypes, Journal of Agricultural and Food Chemistry $\mathbf{5 6}$ (2008), 696-704.

[45] S. Tulipani, G. Marzban, A. Herndl, M. Laimer, B. Mezzetti and M. Battino, Influence of environmental and genetic factors on health-related compounds in strawberry, Food Chemistry 124 (2011), 906-913.

[46] S. Tulipani, B. Mezzetti and M. Battino, Impact of strawberries on human health: Insight into marginally discussed bioactive compounds for the Mediterranean diet, Public Health Nutrition 12 (2009), 1656-1662.

[47] S.Y. Wang and M.J. Camp, Temperatures after bloom affect plant growth and fruit quality of strawberry, Scientia Horticulturae $\mathbf{8 5}$ (2000), 183-199.

[48] S.Y. Wang and P. Millner, Effect of different cultural systems on antioxidant capacity, phenolic content, and fruit quality of strawberries (Fragaria x ananassa Duch.), Journal of Agricultural and Food Chemistry 57 (2009), 9651-9657.

[49] S.Y. Wang and W. Zheng, Effect of plant growth temperature on antioxidant capacity in strawberry, Journal of Agricultural and Food Chemistry 49 (2001), 4977-4982.

[50] S.Y. Wang, W. Zheng and G.J. Galletta, Cultural system affects fruit quality and antioxidant capacity in strawberries, Journal of Agricultural and Food Chemistry 50 (2002), 6534-6542. 